\title{
Upgrading of Light Bio-oil from Solvothermolysis Liquefaction of an Oil Palm Empty Fruit Bunch in Glycerol by Catalytic Hydrodeoxygenation Using NiMo/ $/ \mathrm{Al}_{2} \mathrm{O}_{3}$ or $\mathrm{CoMo} / \mathrm{Al}_{2} \mathrm{O}_{3}$ Catalysts
}

\author{
Chutanan Muangsuwan, Warangthat Kriprasertkul, Sakhon Ratchahat, Chen-Guang Liu, \\ Pattaraporn Posoknistakul, Navadol Laosiripojana, and Chularat Sakdaronnarong*
}

Cite This: ACS Omega 2021, 6, 2999-3016

Read Online

ABSTRACT: Hydrodeoxygenation (HDO) of bio-oil derived from liquefaction of a palm empty fruit bunch (EFB) in glycerol was investigated. To enhance the heating value and reduce the oxygen content of upgraded bio-oil, hydrodeoxygenation of light bio-oil over $\mathrm{Ni}$ - and Co-based catalysts on an $\mathrm{Al}_{2} \mathrm{O}_{3}$ support was performed in a rotating-bed reactor. Two consecutive steps were conducted to produce bio-oil from EFB including (1) microwaveassisted wet torrefaction of $\mathrm{EFB}$ and (2) solvothermolysis liquefaction of treated $\mathrm{EFB}$ in a $\mathrm{Na}_{2} \mathrm{CO}_{3}$ /glycerol system. The $\mathrm{HDO}$ of as-prepared bio-oil was subsequently performed in a unique design reactor possessing a rotating catalyst bed for efficient interaction of a catalyst with bio-oil and facile separation of the catalyst from upgraded bio-oil after the reaction. The reaction was

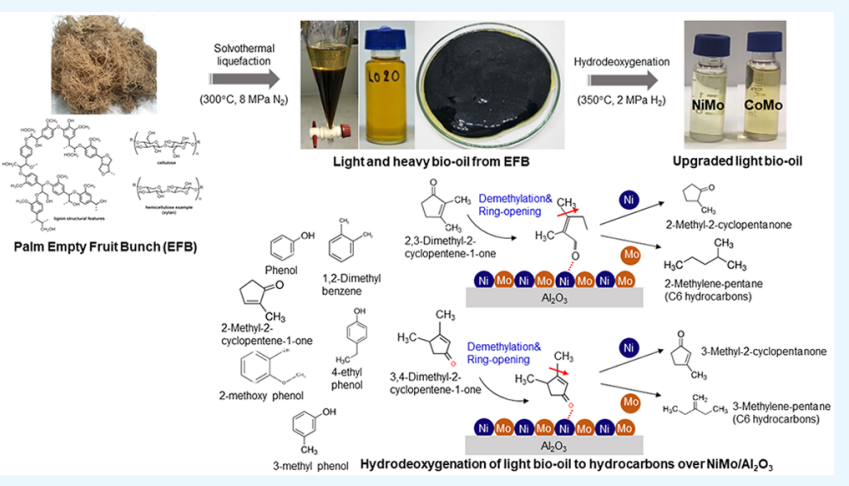
carried out in the presence of each mono- or bimetallic catalyst, namely, Co/ $\mathrm{Al}_{2} \mathrm{O}_{3}, \mathrm{Ni} / \mathrm{Al}_{2} \mathrm{O}_{3}, \mathrm{NiMo} / \mathrm{Al}_{2} \mathrm{O}_{3}$, and $\mathrm{CoMo} / \mathrm{Al}_{2} \mathrm{O}_{3}$, packed in the rotating-mesh host with a rotation speed of $250 \mathrm{rpm}$ and kept at 300 and $350{ }^{\circ} \mathrm{C}, 2 \mathrm{MPa}$ hdrogen for $1 \mathrm{~h}$. From the results, the qualities of upgraded bio-oil were substantially improved for all catalysts tested in terms of oxygen reduction and increased high heating value $(\mathrm{HHV})$. Particularly, the $\mathrm{NiMo} / \mathrm{Al}_{2} \mathrm{O}_{3}$ catalyst exhibited the most promising catalyst, providing favorable bio-oil yield and HHV. Remarkably greater energy ratios and carbon recovery together with high $\mathrm{H} / \mathrm{O}, \mathrm{C} / \mathrm{O}$, and $\mathrm{H} / \mathrm{C}$ ratios were additionally achieved from the $\mathrm{NiMo} / \mathrm{Al}_{2} \mathrm{O}_{3}$ catalyst compared with other catalysts. Cyclopentanone and cyclopentene were the main olefins found in hydrodeoxygenated bio-oil derived from liquefied EFB. It was observed that cyclopentene was first generated and subsequently converted to cyclopentanone under the hydrogenation reaction. These compounds can be further used as a building block in the synthesis of jet-fuel range cycloalkanes.

\section{INTRODUCTION}

Conversion of lignocellulosic biomass into chemicals, fuels, and building blocks for material synthesis such as dehydration of sugars (e.g., glucose, fructose, and xylose) into furans, ${ }^{1}$ hydrogenation of furans into fine chemicals, 2,5-furandicarboxylic acid (FDCA), ${ }^{2}$ and cellulose-based materials ${ }^{3}$ has been intensively studied during past decades regarding the sustainable development goals. Apart from that, liquefaction of biomass has been recently taken into consideration as it is an environmentally friendly route to convert biomass into crude bio-oil and carbon material. The bio-oil as a liquid product can potentially replace petroleum fuels as a renewable energy source, while carbon material can also be upvalued to a precise functional material for various applications such as carbon fibers, carbon clothes, supercapacitors, carbon-based batteries, carbon quantum dots, etc. In thermal liquefaction conversion of biomass, solvothermolysis in the presence of a solvent has been reported to have advantages due to relatively lower operating temperatures $\left(100-200{ }^{\circ} \mathrm{C}\right)$, reduction of tar formation via a cross- linked reaction, ${ }^{4}$ and enhancement of hydrogen donation to the hydrocarbon (HC) structure of the bio-oil product. ${ }^{5}$ Various solvents have been studied for their influence on the dissolution of the biomass matrix during liquefaction including ethylene glycol, poly(ethylene glycol), ethanol, acetone, $n$-dodecane, and phenol. ${ }^{6-8}$ Among all solvents investigated, glycerol is an attractive, renewable, and sustainable biosolvent derived as a byproduct from biodiesel production. ${ }^{9}$ Apart from increasing the dissolution effectiveness of biomass constituents, solvents additionally play a vital role as a hydrogen donor when the hydrogenation reaction is performed at a moderate pressure by

Received: November 4, 2020

Accepted: January 8, 2021

Published: January 21, 2021 
improving the hydrogen transfer toward the biomass structure and thus boosting up the liquid oil yield with oxygen reduction. The use of glycerol as a hydrogen-donor solvent is a striking means as it is a biobased and renewable solvent relative to polyhydric alcohols. According to the previous studies of bio-oil derived from biomass via thermochemical conversion, the quality of bio-oil was not good enough to be used directly after the conversion process. ${ }^{10}$ Therefore, it is necessary to improve the quality of bio-oils similar to that of petroleum fuels by reducing oxygen content, enhancing heating value, and improving physical properties.

Analogous to the hydrotreatment of petroleum fuels, upgrading of biomass liquefied bio-oil using hydrodeoxygenation (HDO) has been intensively studied. HDO is a series of reactions that occur during thermohydrolysis biomass conversion. The HDO reactions mainly include dehydrogenation, decarboxylation, decarbonylation, dehydration, isomerization, and hydrogenolysis of $\mathrm{C}-\mathrm{O}$ and $\mathrm{C}-\mathrm{O}-\mathrm{C}$ bonds. ${ }^{11}$ Hydrogenation of carbonyls and $\mathrm{C}=\mathrm{C}$ bonds or $\mathrm{C}-\mathrm{C}$ bond cleavages during decarbonylation/decarboxylation is the reaction occurring at metal sites. Hence, the type of metallic sites (e.g., monometallic and bimetallic sites) greatly influences the HDO product selectivity, while the solid acid support facilitates the dehydration reaction. Under severe HDO conditions, the stability of metal particles is additionally critical for metal site selection of the designed catalyst since the sintering and leaching of metals often occur due to the high organic and water content in these reactions. This obstacle is overcome by the use of noblemetal catalysts. Lately, $\mathrm{Pt}, \mathrm{Pd}$, and $\mathrm{Ru}$ have been reported to exhibit good catalytic performance in such a process ${ }^{12-14}$ since they are more stable than base metal catalysts. However, the applicability of these precious noble metals is hindered by their high costs.

Recently, transition metals (e.g., Ni, Co, and Mo) have been found to be extremely active catalysts for bio-oil reforming to aromatic hydrocarbons. ${ }^{15-18}$ Earlier studies have reported on the catalytic activity of CoMo and NiMo catalysts over different supports (e.g., $\mathrm{Al}_{2} \mathrm{O}_{3}, \mathrm{SiO}_{2}$, activated carbon, zeolite, etc.) for hydrotreating, hydrocracking, and HDO of vegetable oils, waste cooking oil, and triglyceride model compounds for removing oxygen from these oxygenated feeds. ${ }^{19-22}$ Very recent studies have found that $\mathrm{Ni}-\mathrm{W}$ over a $\mathrm{SiO}_{2}-\mathrm{Al}_{2} \mathrm{O}_{3}$ support substantially enhanced the hydrogenation ability of plant-oil triglycerides to aviation biokerosene compared to molybdenum-based catalyst (CoMo, NiMo) systems. ${ }^{23}$ The study demonstrated that sulfided $\mathrm{Ni}-\mathrm{W} / \mathrm{SiO}_{2}-\mathrm{Al}_{2} \mathrm{O}_{3}$ favored the enhanced hydrocracking of waste soya oil to kerosene, while $\mathrm{Ni}-\mathrm{Mo} / \mathrm{Al}_{2} \mathrm{O}_{3}$ facilitated highly active hydrotreatment of it to produce diesel range hydrocarbons. ${ }^{24}$ Later, the HDO of guaiacol as a model compound containing mainly bio-oil ${ }^{17}$ was studied in a batch reactor at $523 \mathrm{~K}, 5.5 \mathrm{MPa}$ of $\mathrm{H}_{2}$ in the presence of NiMo and CoMo biometallic catalysts on the potassium-modified $\gamma-\mathrm{Al}_{2} \mathrm{O}_{3}$ supporter. It was reported that potassium could increase the selectivity and enhance the yields of products. The main reasons were that (1) the potassium-modified support presumably shifted selectivity from the demethylation and methyl substitution reactions toward the $\mathrm{C}_{\text {Aromatic }}-\mathrm{OH}$ bond, (2) it could reduce the acidity of the supporter, and thus (3) it prevented catalyst coking on the catalyst surface.

By far, most of the studies on HDO focus on the reaction of model compounds or synthetic diesel from vegetable oils whose chemical structure of the substrate is known. The aim of this investigation was to study the appropriate factors for upgrading bio-oils from solvothermolysis liquefaction of more complex structural biomass. Therefore, the influence of HDO conditions and catalysts, mono- and bimetallic, on a metal support was investigated. Moreover, the energy ratio that includes the yield and high heating value (HHV) due to the deoxygenation process was used to assess the quality of upgraded bio-oil based on raw biomass for the efficient evaluation of biofuels property.

\section{RESULTS AND DISCUSSION}

2.1. Characterization of Catalysts. The suitable temperature for hydrogen reduction of each catalyst was determined by $\mathrm{H}_{2}$-temperature-programmed reduction $\left(\mathrm{H}_{2}\right.$-TPR) analysis. Figure 1 shows the $\mathrm{H}_{2}$-TPR profiles of $\mathrm{Ni} / \mathrm{Al}_{2} \mathrm{O}_{3}, \mathrm{Co} / \mathrm{Al}_{2} \mathrm{O}_{3}$,

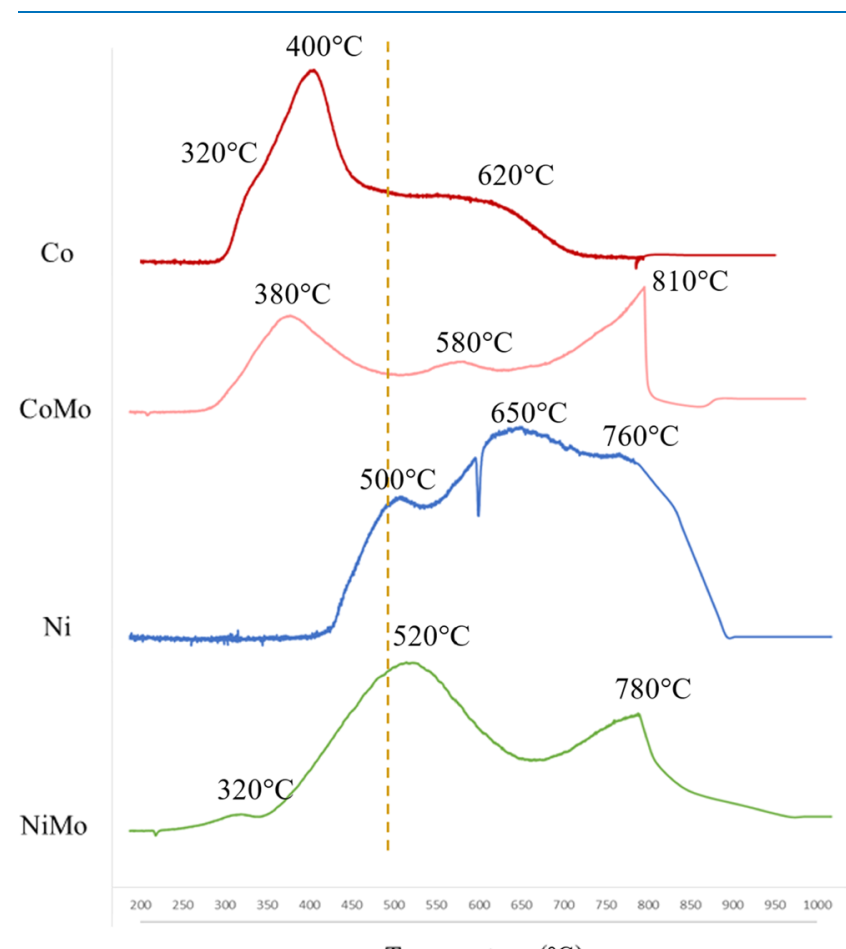

Temperature $\left({ }^{\circ} \mathrm{C}\right)$

Figure 1. $\mathrm{H}_{2}$-TPR analysis of synthesized catalysts, namely, Co, CoMo, $\mathrm{Ni}$, and NiMo supported on $\mathrm{Al}_{2} \mathrm{O}_{3}$.

$\mathrm{NiMo} / \mathrm{Al}_{2} \mathrm{O}_{3}$, and $\mathrm{CoMo} / \mathrm{Al}_{2} \mathrm{O}_{3}$ catalysts. In the case of $\mathrm{Co} /$ $\mathrm{Al}_{2} \mathrm{O}_{3}$, two distinct peaks at around 400 and $620{ }^{\circ} \mathrm{C}$ were observed. The larger peak at $400{ }^{\circ} \mathrm{C}$ indicated a higher consumption of hydrogen during reduction, which referred to the principal transformation of $\mathrm{CoO}$ into a $\mathrm{Co}^{0}$ form. This result was in good agreement with a previous work demonstrating that the main reduction peaks from $\mathrm{H}_{2}$-TPR of cobalt on ZSM-5 zeolite at temperatures lower than $400{ }^{\circ} \mathrm{C}$ were ascribed to the reduction of $\mathrm{Co}_{3} \mathrm{O}_{4}$ that proceeds via a multistep mechanism (reduction of $\mathrm{Co}_{3} \mathrm{O}_{4}$ to $\mathrm{CoO}$ and then to metallic $\mathrm{Co}$ ). ${ }^{25}$ The second peak at $\sim 620{ }^{\circ} \mathrm{C}$ was related to the oxides of cobalt toward an alumina support that were more difficult to reduce due to the stronger interaction between the metal sites and the support. ${ }^{26}$ For the reduction shoulder peak near $320^{\circ} \mathrm{C}$ of $\mathrm{Co} /$ $\mathrm{Al}_{2} \mathrm{O}_{3}$, it was reported that $\mathrm{Co}_{3} \mathrm{O}_{4}$ is relatively easy to reduce (below $450{ }^{\circ} \mathrm{C}$ ), while $\mathrm{CoAl}_{2} \mathrm{O}_{4}$ is very difficult to reduce (above $\left.700{ }^{\circ} \mathrm{C}\right)$. Wang and Chen studied the reduction of pure $\mathrm{Co}_{3} \mathrm{O}_{4}$ and found that for small loading of $\mathrm{Co}$, only one broad peak exists, which belongs to the stepwise reduction of cobalt oxide via $\mathrm{Co}^{3+} \rightarrow \mathrm{Co}^{2+} \rightarrow \mathrm{Co}^{0} .{ }^{27}$ Therefore, the first peak may 

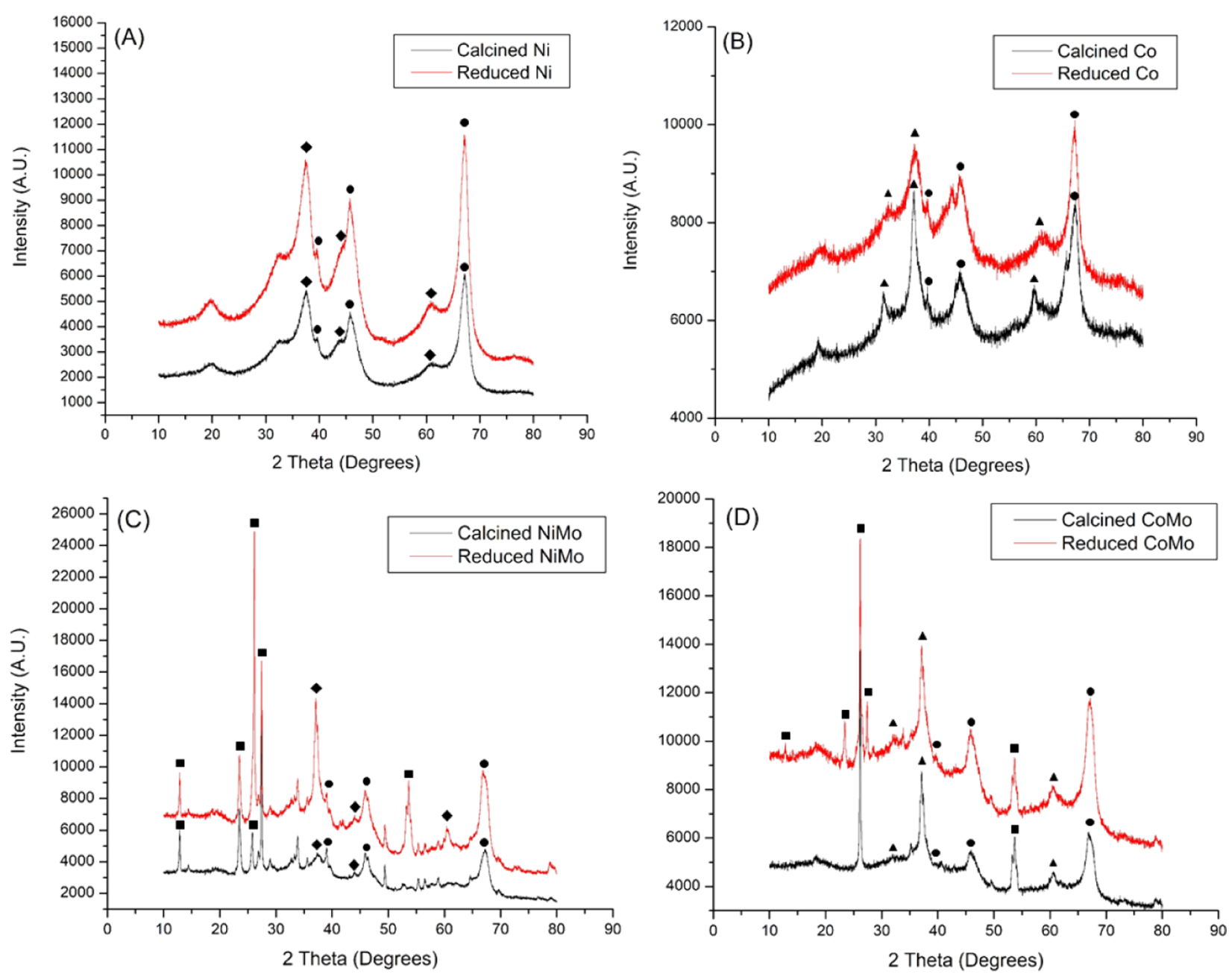

Figure 2. XRD patterns of as-synthesized and hydrogen-reduced (A) Ni, (B) Co, (C) NiMo, and (D) CoMo supported on $\mathrm{Al}_{2} \mathrm{O}_{3}$ when $\bullet$ represents $\mathrm{Al}_{2} \mathrm{O}_{3}, \diamond$ represents $\mathrm{Ni}$ oxides, $\boldsymbol{\Delta}$ represents Co oxides, and $\mathbf{\square}$ represents Mo oxides.

correspond to the reduction of highly dispersed $\mathrm{Co}_{3} \mathrm{O}_{4}$ and the second may correspond to a $\mathrm{CoAl}_{2} \mathrm{O}_{4}$-like phase. ${ }^{28}$

The reduction profile of $\mathrm{Ni} / \mathrm{Al}_{2} \mathrm{O}_{3}$ also showed two peaks at 500 and $650{ }^{\circ} \mathrm{C}$. The major peak at $500{ }^{\circ} \mathrm{C}$ was assigned to the transition of $\mathrm{NiO}$ to metallic $\mathrm{Ni}^{0}$. The strong peak at $650{ }^{\circ} \mathrm{C}$ possibly involved the stronger metal-support interaction or the reduction of oxide $\mathrm{Ni}$ aluminate forms. In addition, the TPR profile of $\mathrm{Ni} / \mathrm{Al}_{2} \mathrm{O}_{3}$ reports that a large reduction peak at $\sim 760$ ${ }^{\circ} \mathrm{C}$ and a shoulder at around $500{ }^{\circ} \mathrm{C}$ were associated with the reduction of $\mathrm{NiO}$ intensely interacting and weakly interacting with the alumina support, respectively. ${ }^{29}$ A study by Maia and colleagues also demonstrated the similar reduction patterns of the $\mathrm{Ni}$ /zeolite catalyst and proposed three reduction zones: (a) $430-470{ }^{\circ} \mathrm{C}$, (b) $520-560^{\circ} \mathrm{C}$, and (c) $630-720^{\circ} \mathrm{C}$. The first reduction zone can be attributed to the bulk $\mathrm{NiO}$, and the latter two could be due to the smaller $\mathrm{NiO}$ particles. Besides, it was also concluded that $\mathrm{Ni}^{2+}$ requires a higher temperature to reduce if it is exchanged with $\mathrm{H}^{+}$on the metal oxide of the support structure. $^{30}$ Therefore, in this case, it can be suggested that bulk $\mathrm{NiO}$ and smaller $\mathrm{NiO}$ particles with strong oxide interaction of the support were present in the catalyst. This could be further confirmed by X-ray diffraction (XRD) characterization.

For bimetallic catalyst reduction, the reduction profile of $\mathrm{CoMo} / \mathrm{Al}_{2} \mathrm{O}_{3}$ showed three peaks at 380,580 , and $810^{\circ} \mathrm{C}$. The major peak is assigned to the transition of $\mathrm{CoO}$ to $\mathrm{Co}^{0}$. It has been observed that the second peak at $\sim 580{ }^{\circ} \mathrm{C}$ in the intermediate-temperature zone is assigned to the hydrogen reduction of $\mathrm{MoO}_{3}\left(\mathrm{Mo}^{6+}\right)$ to $\mathrm{MoO}_{2}\left(\mathrm{Mo}^{4+}\right)$. The reduction temperature ranging from 700 to $850{ }^{\circ} \mathrm{C}$ is associated with the complete reduction of $\mathrm{Mo}(\mathrm{IV})$ to metallic $\mathrm{Mo}^{0}$. A similar report also detected the analogous hydrogen consumption peaks of $\mathrm{CoMo} / \mathrm{Al}_{2} \mathrm{O}_{3}$ in a broad temperature range from $\sim 350$ to 950 ${ }^{\circ} \mathrm{C}$ which are composed of three major reduction peaks at 436 , 577, and $812{ }^{\circ} \mathrm{C}$. $^{31} \mathrm{~A}$ high-temperature region with one dominant peak additionally corresponds to the reduction of oxide Co aluminate forms and deeper reduction of $\mathrm{Mo}^{4+}$ into metallic $\mathrm{Mo}^{0}{ }^{32}$ The reduction profile of $\mathrm{NiMo} / \mathrm{Al}_{2} \mathrm{O}_{3}$ showed three peaks at 320,520 , and $780^{\circ} \mathrm{C}$. The major peak at $550{ }^{\circ} \mathrm{C}$ is assigned to the transition of $\mathrm{NiO}$ to $\mathrm{Ni}^{0}$. The moderate peak at around $800{ }^{\circ} \mathrm{C}$ is assigned to the transition of both $\mathrm{MoO}_{2}$ $\left(\mathrm{Mo}^{4+}\right)$ to $\mathrm{MoO}\left(\mathrm{Mo}^{2+}\right)$ and further reduction of $\mathrm{Mo}^{2+}$ into a metallic $\mathrm{Mo}^{0}$ form. The small shoulder at $320{ }^{\circ} \mathrm{C}$ was reported on the reduction of unbounded free $\mathrm{NiO}$ in the temperature range of 240 and $260{ }^{\circ} \mathrm{C} .{ }^{33}$ The introduction of Mo into nickel catalysts modified the reduction process and caused the decay of the peak connected with unbound $\mathrm{NiO}$. Compared with the $\mathrm{Ni}$ / $\mathrm{Al}_{2} \mathrm{O}_{3}$ peak, the reduced nickel peak significantly decreased with the addition of $\mathrm{Mo}$, probably due to their strong interaction. ${ }^{34}$

The XRD technique was used to explain the crystal morphology of the presence of $\mathrm{Co}, \mathrm{Ni}$, and $\mathrm{Mo}$ on the $\mathrm{Al}_{2} \mathrm{O}_{3}$ 

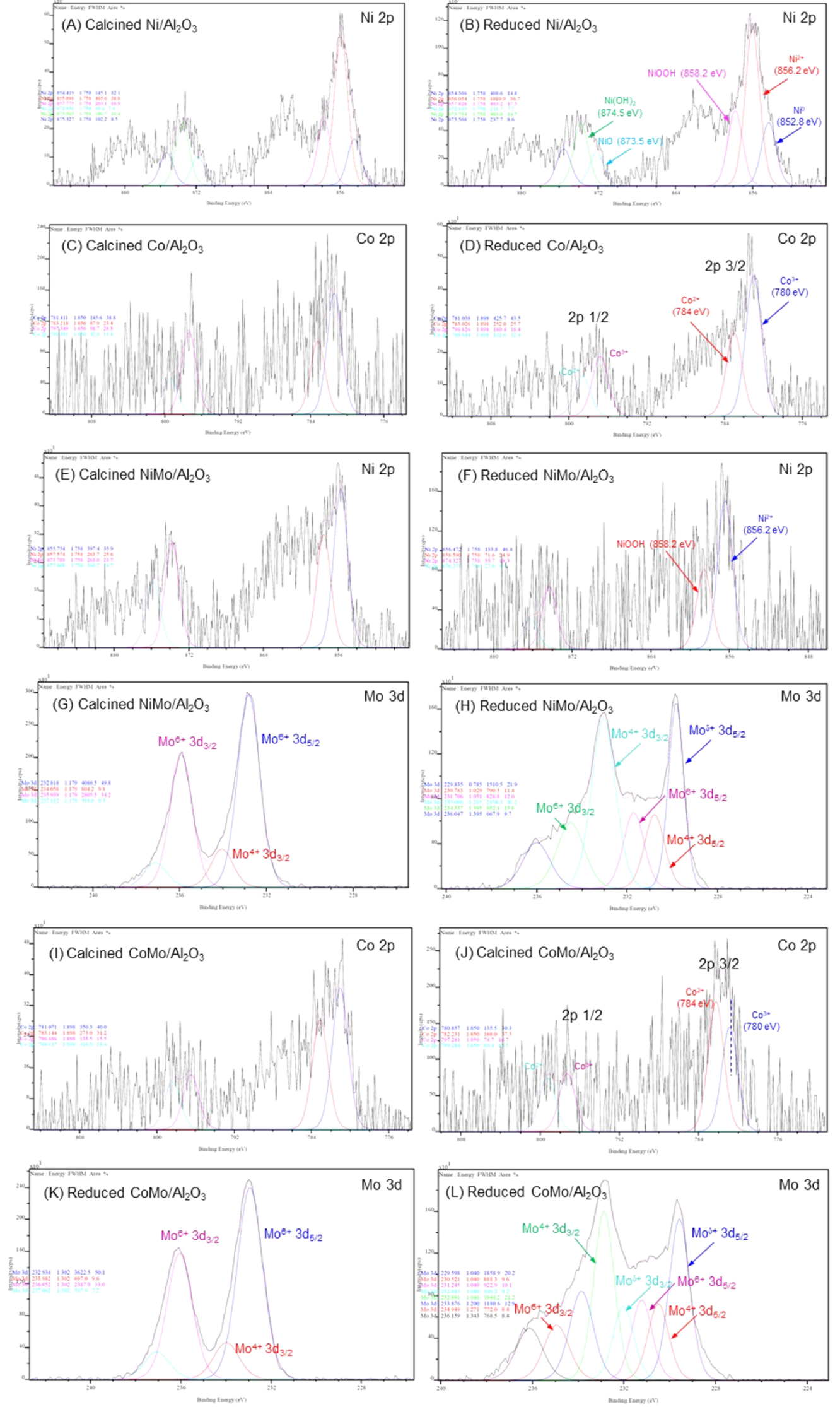

Figure 3. XPS spectra of (A) calcined and (B) reduced $\mathrm{Ni} / \mathrm{Al}_{2} \mathrm{O}_{3}$ for Ni 2p; (C) calcined and (D) reduced Co/ $\mathrm{Al}_{2} \mathrm{O}_{3}$ for Co $2 \mathrm{p}$; (E) calcined and (F) reduced $\mathrm{NiMo} / \mathrm{Al}_{2} \mathrm{O}_{3}$ for $\mathrm{Ni} 2 \mathrm{p} ;(\mathrm{G})$ calcined and $(\mathrm{H})$ reduced $\mathrm{NiMo} / \mathrm{Al}_{2} \mathrm{O}_{3}$ for Mo 3d; (I) calcined and $(\mathrm{J})$ reduced $\mathrm{CoMo} / \mathrm{Al}_{2} \mathrm{O}_{3}$ for $\mathrm{Co} 2 \mathrm{p}$; and $(\mathrm{K})$ calcined and $(\mathrm{L})$ reduced $\mathrm{CoMo} / \mathrm{Al}_{2} \mathrm{O}_{3}$ for $\mathrm{Mo} 3 \mathrm{~d}$. 
support. XRD runs recorded at a $2 \theta$ angular range of $10-80^{\circ}$ are shown in Figure 2. The peaks for $\mathrm{Co}, \mathrm{Ni}$, and Mo were observed for the oxide phases prior to the hydrogen reduction. In all synthesized catalysts, $\mathrm{XRD}$ peaks of $\mathrm{Al}_{2} \mathrm{O}_{3}$ were detected at $2 \theta=$ 38,46 , and $68^{\circ}$ corresponding to a report on the characterization of pure $\gamma-\mathrm{Al}_{2} \mathrm{O}_{3}$ that showed the diffraction peaks at $2 \theta=37,40$, 46, and $67^{\circ} .{ }^{35}$ As demonstrated in Figure $2 \mathrm{~A}, \mathrm{C}, \mathrm{NiO}$ shows the peaks at $2 \theta=37,43$, and $63^{\circ} .^{36}$ After reduction of $\mathrm{Ni} / \mathrm{Al}_{2} \mathrm{O}_{3}$ and $\mathrm{NiMo} / \mathrm{Al}_{2} \mathrm{O}_{3}$ under a $\mathrm{H}_{2}$ atmosphere, $\mathrm{NiO}$ peaks were more intense relative to those of calcined catalysts. It was previously reported that the peak intensity increased with an increase in calcination temperature. This was indicated by the enhanced degree of crystallization of $\mathrm{NiO} .^{36}$ Therefore, the calcination temperature is a crucial factor and it should be high enough to control the characteristics of $\mathrm{NiO}$. In Figure 2B, the Comodified catalyst exhibited peak positions i.e., cobalt(II, III) oxide $\left(\mathrm{Co}_{3} \mathrm{O}_{4}\right)$, at $2 \theta=32,37,45,58$, and $66^{\circ} .{ }^{37,38}$ Therefore, the $\mathrm{XRD}$ pattern in this study was confirmed for the cobalt oxide $\left(\mathrm{Co}_{3} \mathrm{O}_{4}\right)$ peak of both $\mathrm{Co} / \mathrm{Al}_{2} \mathrm{O}_{3}$ and $\mathrm{CoMo} / \mathrm{Al}_{2} \mathrm{O}_{3}$ catalysts at $2 \theta=32,37,45$, and $66^{\circ}$. Only the $\mathrm{Co} / \mathrm{Al}_{2} \mathrm{O}_{3}$ catalyst showed noticeable peaks of $\mathrm{Co}^{2+}$ and $\mathrm{Co}^{3+}$ in $\mathrm{Co}_{3} \mathrm{O}_{4}$ compound at $2 \theta=$ 45 and $66^{\circ}$ because of the higher loading of Co (5 wt \%) on the support compared with CoMo (2.5 wt \%). The XRD patterns matched characteristic peaks of cobalt(II) oxide in the form of $\mathrm{Co}_{3} \mathrm{O}_{4}$ rather than $\mathrm{CoO}$ for both calcined and reduced $\mathrm{Co} /$ $\mathrm{Al}_{2} \mathrm{O}_{3}$ and $\mathrm{CoMo} / \mathrm{Al}_{2} \mathrm{O}_{3}$. Thus, overlapping peaks of $\mathrm{Co}_{3} \mathrm{O}_{4}$, $\mathrm{NiO}$, and $\mathrm{Al}_{2} \mathrm{O}_{3}$ were found at $37^{\circ}$. In the case of bimetallic $\mathrm{NiMo} / \mathrm{Al}_{2} \mathrm{O}_{3}$ and $\mathrm{CoMo} / \mathrm{Al}_{2} \mathrm{O}_{3}$ catalysts (Figure 2C,D), XRD peaks of molybdenum oxides $\left(\mathrm{Mo}^{6+}\right.$ or $\mathrm{MoO}_{3}$ phase) were detected at a $2 \theta$ of $12.7,23.5,25.8,27.3$, and $33.9^{\circ 39}$ from calcined catalysts. After hydrogen reduction of the NiMO/ $\mathrm{Al}_{2} \mathrm{O}_{3}$ catalyst, three peaks were prominently observed at 26.1, 37.0 , and $53.5^{\circ}$, which correspond to $\mathrm{MoO}_{2}$ or $\mathrm{Mo}^{4+} \cdot{ }^{40}$ This demonstrated the transition of $\mathrm{Mo}^{6+}$ to $\mathrm{Mo}^{4+}$ after hydrogen reduction of the calcined catalyst as shown in Figure 2C. For reduced $\mathrm{CoMo} / \mathrm{Al}_{2} \mathrm{O}_{3}$, the weak peaks at $2 \theta=26.51$ and $27.5^{\circ}$ corresponding to the (002) and (112) planes of $\mathrm{CoMoO}_{4}$, respectively, were observed. ${ }^{41}$ On comparing XRD patterns of NiMo and CoMo on the $\mathrm{Al}_{2} \mathrm{O}_{3}$ support, the higher intensity of Mo peaks was found in $\mathrm{NiMo} / \mathrm{Al}_{2} \mathrm{O}_{3}$, presumably indicating the higher performance of $\mathrm{Mo}$ in catalytic reactivity for bio-oil hydrodeoxygenation.

Binding energy positions of $\mathrm{Ni}^{0}$ and $\mathrm{Ni}^{2+}$ on the $\mathrm{Al}_{2} \mathrm{O}_{3}$ support are at 852.4 and $855.5 \mathrm{eV}$, respectively, for $\mathrm{Ni} 2 \mathrm{p}_{3 / 2}$, which are consistent with the TPR results. There are $\mathrm{NiO}, \mathrm{Ni}(\mathrm{OH})_{2}$, and $\mathrm{NiOOH}$ on the surface of the catalysts after calcination in air and hydrogen reduction shown in Figure 3A,B, respectively. Nevertheless, the X-ray photoelectron spectroscopy (XPS) peak areas of metallic $\mathrm{Ni}^{0}$ and $\mathrm{Ni}^{2+}$ in the $\mathrm{H}_{2}$-reduced catalyst were enhanced almost 2.5 times as much as those in the calcined $\mathrm{Ni} / \mathrm{Al}_{2} \mathrm{O}_{3}$ catalyst. The presence of $\mathrm{NiO}$ may be due to the oxidation of nickel nanoparticles in the air, while an increased $\mathrm{Ni}(\mathrm{OH})_{2}$ and $\mathrm{NiOOH}$ composition is formed by the reaction of $\mathrm{Ni}^{2+}$ with hydrogen gas in the reduction stage. Obviously, it can be seen from the Ni 2p XPS that Ni nanoparticles have been successfully deposited on $\mathrm{Al}_{2} \mathrm{O}_{3}$. It has been demonstrated that the binding energies of free $\mathrm{Ni}, \mathrm{NiO}$ intimately contacted with $\mathrm{Al}_{2} \mathrm{O}_{3}$, and $\mathrm{NiAl}_{2} \mathrm{O}_{4}$ formation into support matrix are different. Free $\mathrm{NiO}\left(\mathrm{Ni} 2 \mathrm{p}_{3 / 2}\right)$ was observed at $853.6 \mathrm{eV}, \mathrm{NiO}$ closely interacted with $\mathrm{Al}_{2} \mathrm{O}_{3}$ was detected at $856.5 \mathrm{eV}$, and spinel $\mathrm{NiAl}_{2} \mathrm{O}_{4}$ was noticed at $857.0 \mathrm{eV}^{42}$ Nevertheless, the XRD results confirm the existence of $\mathrm{NiO}$ instead of the spinel phase of the synthesized $\mathrm{Ni} / \mathrm{Al}_{2} \mathrm{O}_{3}$ catalyst. Although the result from
$\mathrm{H}_{2}$-TPR showed the major peak of transition from $\mathrm{NiO}$ to metallic $\mathrm{Ni}^{0}$ at $550{ }^{\circ} \mathrm{C}$, the ex situ hydrogen reduction of the $\mathrm{Ni}$ / $\mathrm{Al}_{2} \mathrm{O}_{3}$ catalyst at $500{ }^{\circ} \mathrm{C}$ for $1 \mathrm{~h}$ in the catalyst preparation was achieved. Therefore, the $\mathrm{Ni}$ species in the sample calcined and reduced in a hydrogen atmosphere at $500{ }^{\circ} \mathrm{C}$ should be mainly $\mathrm{NiO}$ weakly contacted with the $\mathrm{Al}_{2} \mathrm{O}_{3}$ matrix.

In the case of calcined and reduced $\mathrm{Co} / \mathrm{Al}_{2} \mathrm{O}_{3}$ catalyst demonstrated in Figure $3 \mathrm{C}, \mathrm{D}$, the Co $2 \mathrm{p}$ spectra show the characteristic doublet ( $\mathrm{Co} 2 \mathrm{p}_{3 / 2}$ at $782.1 \mathrm{eV}$ ) corresponding to $\mathrm{Co}^{2+}$ of the $\mathrm{Co} / \mathrm{Al}_{2} \mathrm{O}_{3}$ sample. According to the literature, cobalt oxides $\left(\mathrm{Co}^{2+}\right.$ and $\left.\mathrm{Co}^{3+}\right)$ found in $\mathrm{Co} / \mathrm{Al}_{2} \mathrm{O}_{3}$ from the impregnation method after calcination in air corresponded to $\mathrm{Co}_{3} \mathrm{O}_{4}(780.0 \mathrm{eV}){ }^{43}$ After hydrogen reduction, a greater intensity of all Co XPS peaks was achieved, approximately 2 times compared with those of calcined $\mathrm{Co} / \mathrm{Al}_{2} \mathrm{O}_{3}$ in air. $\mathrm{A}$ distinct peak of $\mathrm{Co}^{3+}$ appeared at the low binding energy side of the $\mathrm{Co} 2 \mathrm{p}_{3 / 2}$ component at $\sim 780 \mathrm{eV}$ in agreement with the $\mathrm{Co}^{2+}$ peak at $784 \mathrm{eV}$ (Figure 3D). The XPS analytical results were in good accordance with $\mathrm{XRD}$ results as $\mathrm{Co}_{3} \mathrm{O}_{4}$, which contained $\mathrm{Co}^{2+}$ and $\mathrm{Co}^{3+}$ in the structure, was observed. Its Co $2 \mathrm{p}_{1 / 2}$ counterpart can also be detected in the spectra. The considerable increase in the XPS intensity of reduced $\mathrm{Co} /$ $\mathrm{Al}_{2} \mathrm{O}_{3}$ relative to calcined $\mathrm{Co} / \mathrm{Al}_{2} \mathrm{O}_{3}$ can be attributed to a different, probably more reduced cobalt state.

For the $\mathrm{NiMo} / \mathrm{Al}_{2} \mathrm{O}_{3}$ catalyst, Figure 3E,F demonstrates two peaks at 856.3 and $873.5 \mathrm{eV}$ in the Ni 2 P XPS spectra assigned to the spin-orbit split lines of $\mathrm{Ni} 2 \mathrm{p}_{3 / 2}$ and $\mathrm{Ni} 2 \mathrm{p}_{1 / 2}$, respectively. The shakeup satellite structures of $\mathrm{Ni} 2 \mathrm{p}_{3 / 2}$ and $\mathrm{Ni} 2 \mathrm{p}_{3 / 2}$ were indicated by two broad peaks at around 862.0 and $880.0 \mathrm{eV}^{44,45}$ as shown in Figure $3 \mathrm{G}, \mathrm{H}$. Therefore, $\mathrm{NiO}, \mathrm{Ni}_{2} \mathrm{O}_{3}$, and spinel $\mathrm{NiAl}_{2} \mathrm{O}_{4}$ forms were present in the $\mathrm{NiMo} / \mathrm{Al}_{2} \mathrm{O}_{3}$ sample due to the $\mathrm{NiO}-\mathrm{Al}_{2} \mathrm{O}_{3}$ interface or $\mathrm{NiO}-\mathrm{MoO}_{3}$ interaction that generates spinel $\mathrm{NiMoO}_{4}$. In contrast to $\mathrm{XRD}$ results, no obvious XPS peak attributed to $\mathrm{NiO}$ but $\mathrm{Ni}_{2} \mathrm{O}_{3}$ and spinel $\mathrm{NiAl}_{2} \mathrm{O}_{4}$ on the surface of $\mathrm{NiMo} / \mathrm{Al}_{2} \mathrm{O}_{3}$ was observed in a range of $853.5-854.5 \mathrm{eV}$ for $\mathrm{Ni} 2 \mathrm{p}_{3 / 2}$.

In the calcined CoMo/ $/ \mathrm{Al}_{2} \mathrm{O}_{3}$ sample, XPS spectra of Co $2 \mathrm{p}$ are similar to those of monometal Co on $\mathrm{Al}_{2} \mathrm{O}_{3}$ (Figure 3I,J). For Mo $3 \mathrm{~d}$ spectra, two prominent peaks of $\mathrm{Mo}^{6+} 3 \mathrm{~d}_{3 / 2}$ and $\mathrm{Mo}^{6+}$ $3 \mathrm{~d}_{5 / 2}$ at binding energies of 235.5 and $232.3 \mathrm{eV}$, respectively, were observed, representing the presence of Mo oxides ${ }^{46}$ (Figure $3 \mathrm{~K}$ ). $\mathrm{Mo}^{4+} 3 \mathrm{~d}_{3 / 2}$ appearing at $234.0 \mathrm{eV}$ was also detected as a small peak. After hydrogen reduction, as shown in Figure 3L, two new peaks were observed at 229.4 and $232.6 \mathrm{eV}$ attributed to $\mathrm{Mo}^{\delta+}(1<\delta<4) 3 \mathrm{~d}_{5 / 2}$ and $\mathrm{Mo}^{\delta+} 3 \mathrm{~d}_{3 / 2}$, respectively. ${ }^{47}$ It was reported that $\mathrm{Mo}^{\delta+}$ species were formed when Mo loading was increased. Relative to the calcined $\mathrm{CoMo} / \mathrm{Al}_{2} \mathrm{O}_{3}$ catalyst, $\mathrm{Mo}^{\delta+}$ $3 \mathrm{~d}_{5 / 2}$ and $\mathrm{Mo}^{4+} 3 \mathrm{~d}_{3 / 2}$ peak intensities were more intense after hydrogen reduction, while $\mathrm{Mo}^{6+}$ substantially decreased. It was moreover observed that the binding energies of $\mathrm{Mo}^{6+}$ and $\mathrm{Mo}^{4+}$ states shifted toward lower levels after hydrogen reduction for both $\mathrm{NiMo} / \mathrm{Al}_{2} \mathrm{O}_{3}$ (Figure $3 \mathrm{H}$ ) and $\mathrm{CoMo} / \mathrm{Al}_{2} \mathrm{O}_{3}$ (Figure $3 \mathrm{~L}$ ). This evidence was additionally confirmed by the XRD patterns of $\mathrm{MoO}_{2}$ occurrence instead of $\mathrm{MoO}_{3}$ after hydrogen reduction of NiMo and CoMo catalysts in Figure 2C,D, respectively. This shifting of the binding energy of $\mathrm{Mo}^{6+}$ and $\mathrm{Mo}^{4+}$ after hydrogen reduction was possibly due to an increased density of electrons that intensified the electromagnetic shield of the inner shell electrons which led to a decrease in binding energy of electrons. $^{40}$

Scanning electron microscopy (SEM) images of all synthesized catalysts, i.e., $\mathrm{Ni} / \mathrm{Al}_{2} \mathrm{O}_{3}, \mathrm{Co} / \mathrm{Al}_{2} \mathrm{O}_{3}, \mathrm{NiMo} / \mathrm{Al}_{2} \mathrm{O}_{3}$, and $\mathrm{CoMo} / \mathrm{Al}_{2} \mathrm{O}_{3}$ are shown in Figure 4. The metal and the 


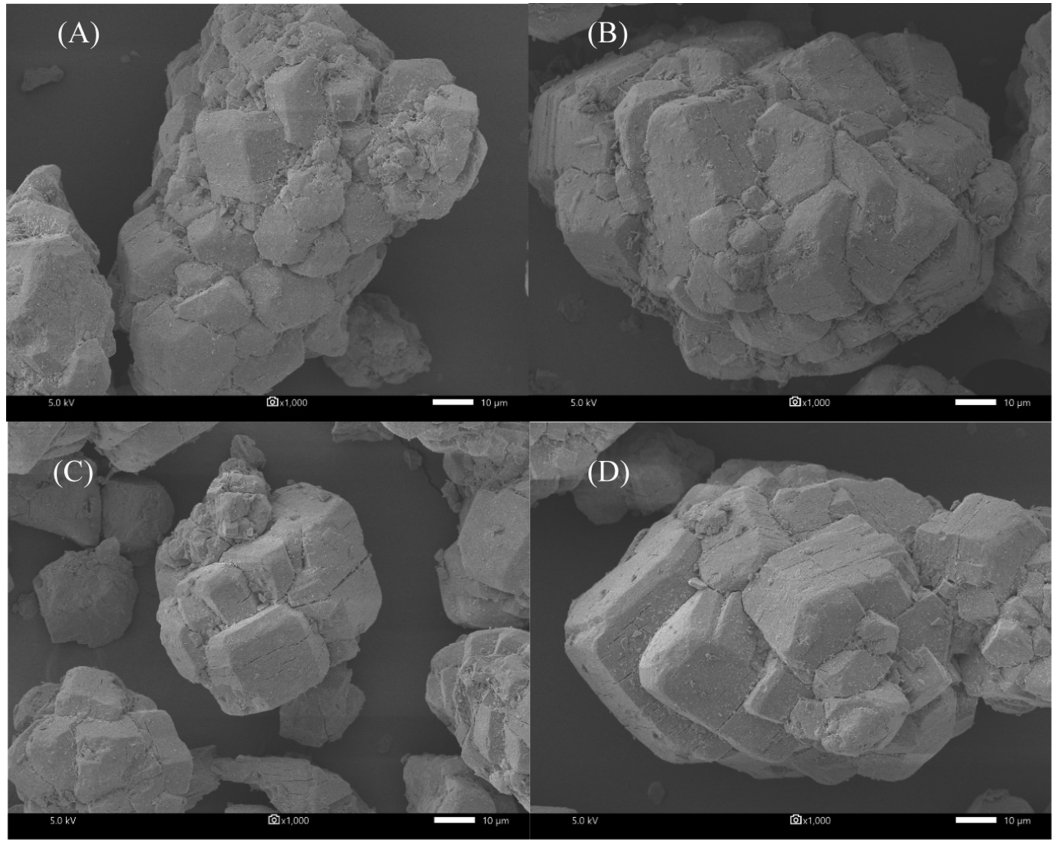

Figure 4. SEM images of $(\mathrm{A}) \mathrm{Co} / \mathrm{Al}_{2} \mathrm{O}_{3},(\mathrm{~B}) \mathrm{CoMo} / \mathrm{Al}_{2} \mathrm{O}_{3},(\mathrm{C}) \mathrm{Ni} / \mathrm{Al}_{2} \mathrm{O}_{3}$, and (D) NiMo/ $\mathrm{Al}_{2} \mathrm{O}_{3}$ catalysts $(1000 \times$ magnification) after calcination at $500{ }^{\circ} \mathrm{C}$ for $5 \mathrm{~h}$.
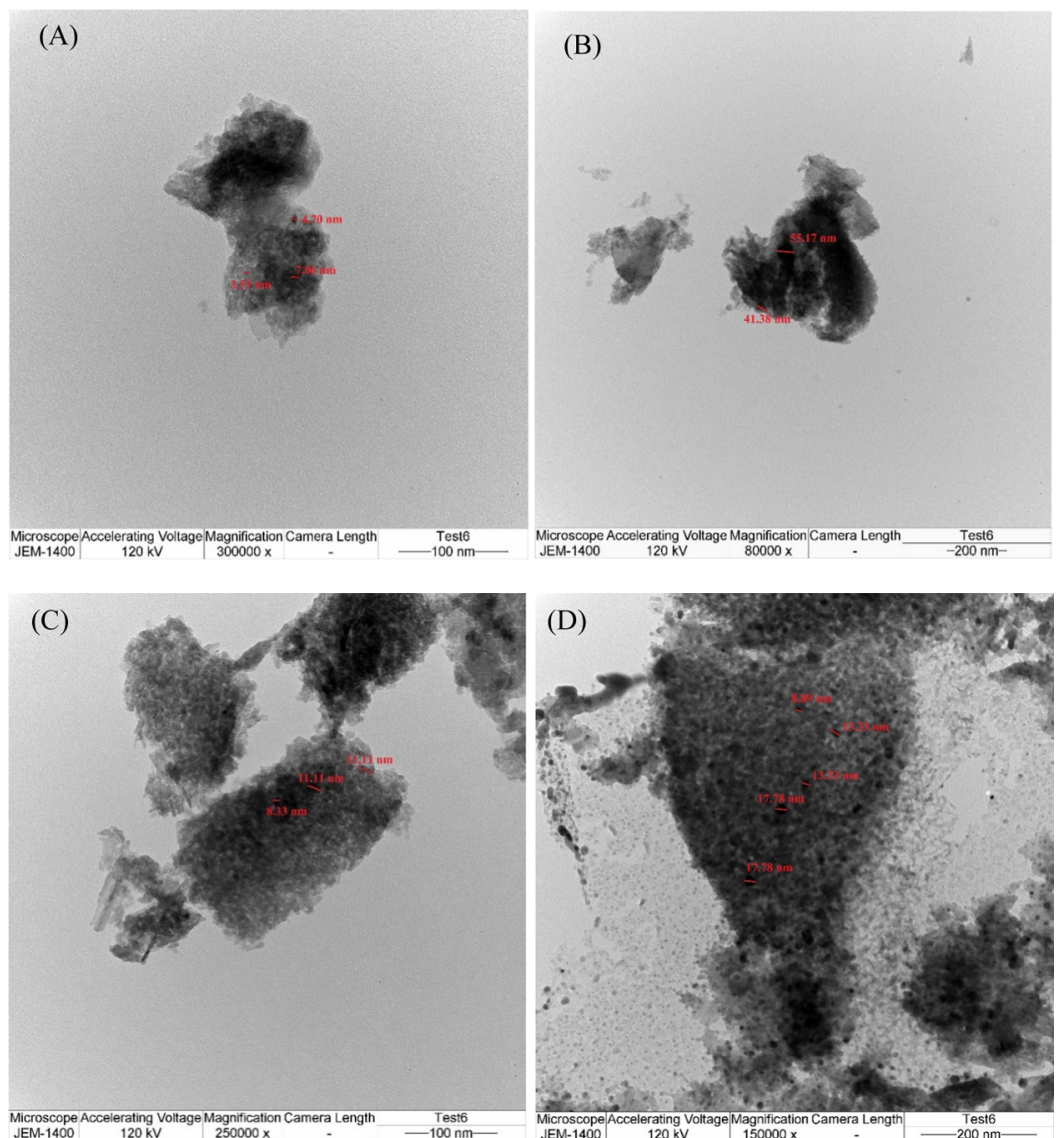

Figure 5. TEM images of (A) $\mathrm{Co} / \mathrm{Al}_{2} \mathrm{O}_{3}\left(300000 \times\right.$ magnification), (B) CoMo/ $\mathrm{Al}_{2} \mathrm{O}_{3}\left(80000 \times\right.$ magnification), (C) $\mathrm{Ni} / \mathrm{Al}_{2} \mathrm{O}_{3}$ (250 000 $\times$ magnification), and (D) $\mathrm{NiMo} / \mathrm{Al}_{2} \mathrm{O}_{3}\left(150000 \times\right.$ magnification) catalysts after calcination at $500{ }^{\circ} \mathrm{C}$ for $5 \mathrm{~h}$.

support were aggregated as crystalline solids and possibly provided a large surface area. These SEM images were comparable with the SEM image of commercial activated alumina from a previous work. ${ }^{48}$ It was observed that the morphology of commercial alumina used as a support in this study showed an unsmooth appearance composed of dense aggregates of lumpy anhedral grains of macrocrystallites. Similarly, the characterization of $\mathrm{NiMo} / \mathrm{Al}_{2} \mathrm{O}_{3}$ and $\mathrm{CoMo} /$ 


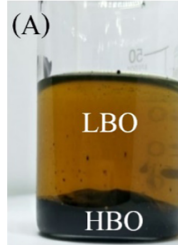

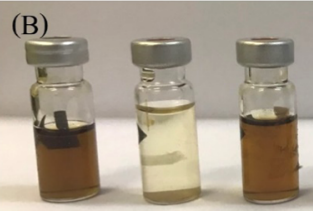

(1)

(2)

(3)

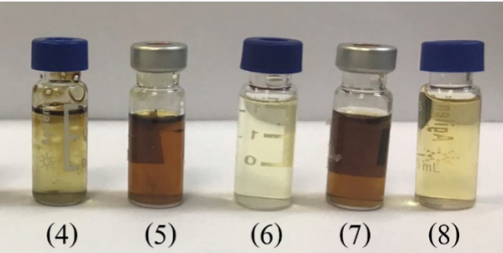

Figure 6. Physical appearance of (A) raw light bio-oil (LBO) and heavy bio-oil (HBO) from solvothermolysis liquefaction of EFB and (B) upgraded light bio-oil from the $\mathrm{HDO}$ reaction using different reaction times and catalysts: (1) Ni/ $\mathrm{Al}_{2} \mathrm{O}_{3} 300{ }^{\circ} \mathrm{C},(2) \mathrm{Ni} / \mathrm{Al}_{2} \mathrm{O}_{3} 350{ }^{\circ} \mathrm{C},(3) \mathrm{Co} / \mathrm{Al}_{2} \mathrm{O}_{3} 300{ }^{\circ} \mathrm{C}$, (4) $\mathrm{Co} / \mathrm{Al}_{2} \mathrm{O}_{3} 350{ }^{\circ} \mathrm{C}$, (5) NiMo/ $\mathrm{Al}_{2} \mathrm{O}_{3} 300{ }^{\circ} \mathrm{C}$, (6) $\mathrm{NiMo} / \mathrm{Al}_{2} \mathrm{O}_{3} 350{ }^{\circ} \mathrm{C}$, (7) $\mathrm{CoMo} / \mathrm{Al}_{2} \mathrm{O}_{3} 300{ }^{\circ} \mathrm{C}$, and (8) $\mathrm{CoMo} / \mathrm{Al}_{2} \mathrm{O}_{3} 350{ }^{\circ} \mathrm{C}$ with $2 \mathrm{MPa}$ hydrogen for $1 \mathrm{~h}$. (Photograph courtesy of Chutanan Muangsuwan. Copyright 2020).

$\mathrm{Al}_{2} \mathrm{O}_{3}$ catalysts by SEM images has shown that the small microcrystallites of metal particles on the alumina surface were estimated to be in a nanosized range. ${ }^{49}$

Further characterization by transmission electron microscopy (TEM) images revealed that metallic $\mathrm{Ni}, \mathrm{Co}, \mathrm{NiMo}$, and CoMo nanoparticles were highly dispersed on the surface of the $\mathrm{Al}_{2} \mathrm{O}_{3}$ support (Figure 5). In contrast to SEM images that illustrate the surface characteristics of the $\mathrm{Al}_{2} \mathrm{O}_{3}$ support using the scanning of an electron beam at a relatively low magnification $(1000 \times)$, TEM image analysis was applied to characterize the morphology and active phase of $\mathrm{Ni}, \mathrm{NiMo}, \mathrm{Co}$, and CoMo on the support at a substantially greater magnification (80 000-300 000X). The particle and size distribution of the active phase of the metal in synthesized catalysts was estimated using the electron transmission technique. TEM images of catalysts showed dark spots of $\mathrm{Co}, \mathrm{Ni}$, and $\mathrm{Mo}$ nanoparticles. The average sizes of each monometallic particle were observed to be 5.1, 48.3, 10.2, and $12.6 \mathrm{~nm}$ for $\mathrm{Co} / \mathrm{Al}_{2} \mathrm{O}_{3}, \mathrm{CoMo} / \mathrm{Al}_{2} \mathrm{O}_{3}, \mathrm{Ni} / \mathrm{Al}_{2} \mathrm{O}_{3}$, and $\mathrm{NiMo} /$ $\mathrm{Al}_{2} \mathrm{O}_{3}$ catalysts, respectively. Zhang et al. ${ }^{50}$ also observed the average sizes of metal particles to be about 7.0 and 5.3 and 7.0 $\mathrm{nm}$ for Ni/HZSM-5 and Co/HZSM-5, respectively, by TEM analyses. Although the resolution of the images affected the characterization of detailed $\mathrm{Al}_{2} \mathrm{O}_{3}$ shape, it appeared as nanosized regular-shaped grains from TEM images. The crystallite sizes of the as-synthesized and commercial $\mathrm{Al}_{2} \mathrm{O}_{3}$ were approximated to be 10.0 and $12.5 \mathrm{~nm}$, respectively. ${ }^{48,51}$ These values were closely comparable with the crystallite size reported for alumina nanoparticles.

The analysis of the Brunauer-Emmett-Teller (BET) surface area of reduced catalysts (Table $\mathrm{S} 1$ ) demonstrated that calcined $\mathrm{Ni} / \mathrm{Al}_{2} \mathrm{O}_{3}\left(1.17 \times 10^{2} \mathrm{~m}^{2} \mathrm{~g}^{-1}\right), \mathrm{Co} / \mathrm{Al}_{2} \mathrm{O}_{3}\left(1.17 \times 10^{2} \mathrm{~m}^{2} \mathrm{~g}^{-1}\right)$, $\mathrm{NiMo} / \mathrm{Al}_{2} \mathrm{O}_{3}\left(1.03 \times 10^{2} \mathrm{~m}^{2} \mathrm{~g}^{-1}\right)$, and $\mathrm{CoMo} / \mathrm{Al}_{2} \mathrm{O}_{3}(9.82 \times$ $\left.10^{1} \mathrm{~m}^{2} \mathrm{~g}^{-1}\right)$ had a lesser surface area compared with the $\mathrm{Al}_{2} \mathrm{O}_{3}$ support $\left(1.27 \times 10^{2} \mathrm{~m}^{2} \mathrm{~g}^{-1}\right)$. All calcined catalysts had a mesoporous structure in a range of $7.22-7.90 \mathrm{~nm}$ pore diameter, indicating that $\mathrm{Ni}, \mathrm{Co}$, and $\mathrm{Mo}$ particles, which have larger crystal sizes from TEM images $(10.2-48.3 \mathrm{~nm})$, were dispersed on the $\mathrm{Al}_{2} \mathrm{O}_{3}$ surface without entering into the mesoporous structures of the support. Moreover, nitrogen adsorptiondesorption isotherms of all calcined catalysts and the $\mathrm{Al}_{2} \mathrm{O}_{3}$ support revealed type IV isotherm profiles according to IUPAC (Figure S3). This was due to capillary condensation, which is accompanied by hysteresis. The type IV isotherm typically occurs when the pore width exceeds a certain critical width (for pores wider than $\sim 4 \mathrm{~nm}$ ), depending on the temperature and system of adsorption. In this case, the pattern of initial monolayer-multilayer adsorption on the mesopore walls is found and subsequently pore condensation is observed.

2.2. Hydrodeoxygenation of Light Bio-oil (LBO) from Empty Fruit Bunch (EFB) Liquefaction. 2.2.1. Physical and Chemical Compositions of Upgraded Bio-oil. After improving the quality of bio-oil by HDO in the presence of various monoand bimetallic catalysts on the $\mathrm{Al}_{2} \mathrm{O}_{3}$ support at different temperatures, the physical appearance of raw bio-oil (Figure $6 \mathrm{~A})$, especially the color, was changed, while the viscosity was observed to be reduced as shown in Figure 6B. It can be seen that the characteristics of bio-oil were enhanced after $\mathrm{HDO}$ with the presence of $\mathrm{Ni} / \mathrm{Al}_{2} \mathrm{O}_{3}, \mathrm{Co} / \mathrm{Al}_{2} \mathrm{O}_{3}, \mathrm{NiMo} / \mathrm{Al}_{2} \mathrm{O}_{3}$, and $\mathrm{CoMo} /$ $\mathrm{Al}_{2} \mathrm{O}_{3}$ catalysts at $350{ }^{\circ} \mathrm{C}$ (Figure $6 \mathrm{~B}(2,4,6$, and 8$)$ ) from which the obtained bio-oil was clearer than those at $300{ }^{\circ} \mathrm{C}$ (Figure $6 \mathrm{~B}(1,3,5$, and 7$))$. Therefore, it could be concluded that upgrading liquefied bio-oils from $\mathrm{EFB}$ at $350{ }^{\circ} \mathrm{C}$ gave a better bio-oil appearance comparable to petroleum fuels. Among all catalysts and temperatures tested, the $\mathrm{HDO}$ of light bio-oil with the $\mathrm{NiMo} / \mathrm{Al}_{2} \mathrm{O}_{3}$ catalyst at $350{ }^{\circ} \mathrm{C}$ yielded the clearest upgraded bio-oil as illustrated in Figure 6B6. This result was in good accordance with hydrodeoxygenation and hydrocracking of crude microalgae bio-oil to gasoline, kerosene, and diesel oil by the commercial $\mathrm{NiMo} / \mathrm{Al}_{2} \mathrm{O}_{3}$ catalyst at $250{ }^{\circ} \mathrm{C},{ }^{52}$ and the deoxygenated products were clearly analogous to petroleum-like fuels. $^{53}$

In terms of chemical compositional analysis of upgraded biooil, Fourier transform infrared (FT-IR) spectroscopy was performed for the qualitative analysis as shown in Figure 7. The FT-IR peak assignment of bio-oil is additionally shown in Table 1 . The results showed that all deoxygenated bio-oils using different catalysts including $\mathrm{Ni} / \mathrm{Al}_{2} \mathrm{O}_{3}, \mathrm{Co} / \mathrm{Al}_{2} \mathrm{O}_{3}, \mathrm{NiMo} / \mathrm{Al}_{2} \mathrm{O}_{3}$, and $\mathrm{CoMo} / \mathrm{Al}_{2} \mathrm{O}_{3}$ contained the same functional groups as the blank without deoxygenation. However, there are considerable differences of peak intensities among all catalysts. The peak no. 1 near $3350 \mathrm{~cm}^{-1}$ represents the $\mathrm{O}-\mathrm{H}$ stretching, indicating polymeric $\mathrm{O}-\mathrm{H}$, alcohols, and phenol found in bio-oil. The peak no. 2 is assigned to $\mathrm{CH}$ and $\mathrm{CH}_{2}$ stretching of alkanes near 1925 and $2960 \mathrm{~cm}^{-1}$, respectively. Another dominant peak (no. 3) is near $2355 \mathrm{~cm}^{-1}$, representing the presence of a $-\mathrm{C}-\mathrm{O}$ group, the peak no. 4 in the range of $1602-1656 \mathrm{~cm}^{-1}$ represents the $-\mathrm{C}=\mathrm{C}-$ group of alkenes, and the peak no. 5 at $1043 \mathrm{~cm}^{-1}$ is attributed to the $-\mathrm{C}-\mathrm{O}$ group of phenols, ester, and ethers. ${ }^{54}$ Compared to the blank without HDO, the bio-oil from HDO has higher peak intensities for the absorbance at 2925 and 2960 $\mathrm{cm}^{-1}$ attributed to higher $\mathrm{CH}$ and $\mathrm{CH}_{2}$ contents in bio-oil due to hydrogenation and deoxygenation reactions. Similarly, the greater peak intensity at $1642 \mathrm{~cm}^{-1}$ of $\mathrm{HDO}$ of bio-oil with catalysts shows the reduction of oxygen groups such as $\mathrm{OH}$ and $\mathrm{C}-\mathrm{O}$, while the amount of $-\mathrm{C}=\mathrm{C}-$ groups increased substantially. In addition, the presence of FTIR peaks at 1650 and $1750 \mathrm{~cm}^{-1}$ represents the $\mathrm{C}=\mathrm{O}$ stretching of ketones, aldehydes, and carboxylic acids. This conclusion is also confirmed by the decline of peaks assigned to hydroxyl groups at around $3350 \mathrm{~cm}^{-1}$ concerning the deoxygenation of aliphatic alcohols to esters. From the results, liquefied bio-oil from biomass was upgraded by elimination of oxygen atoms from 
(A)
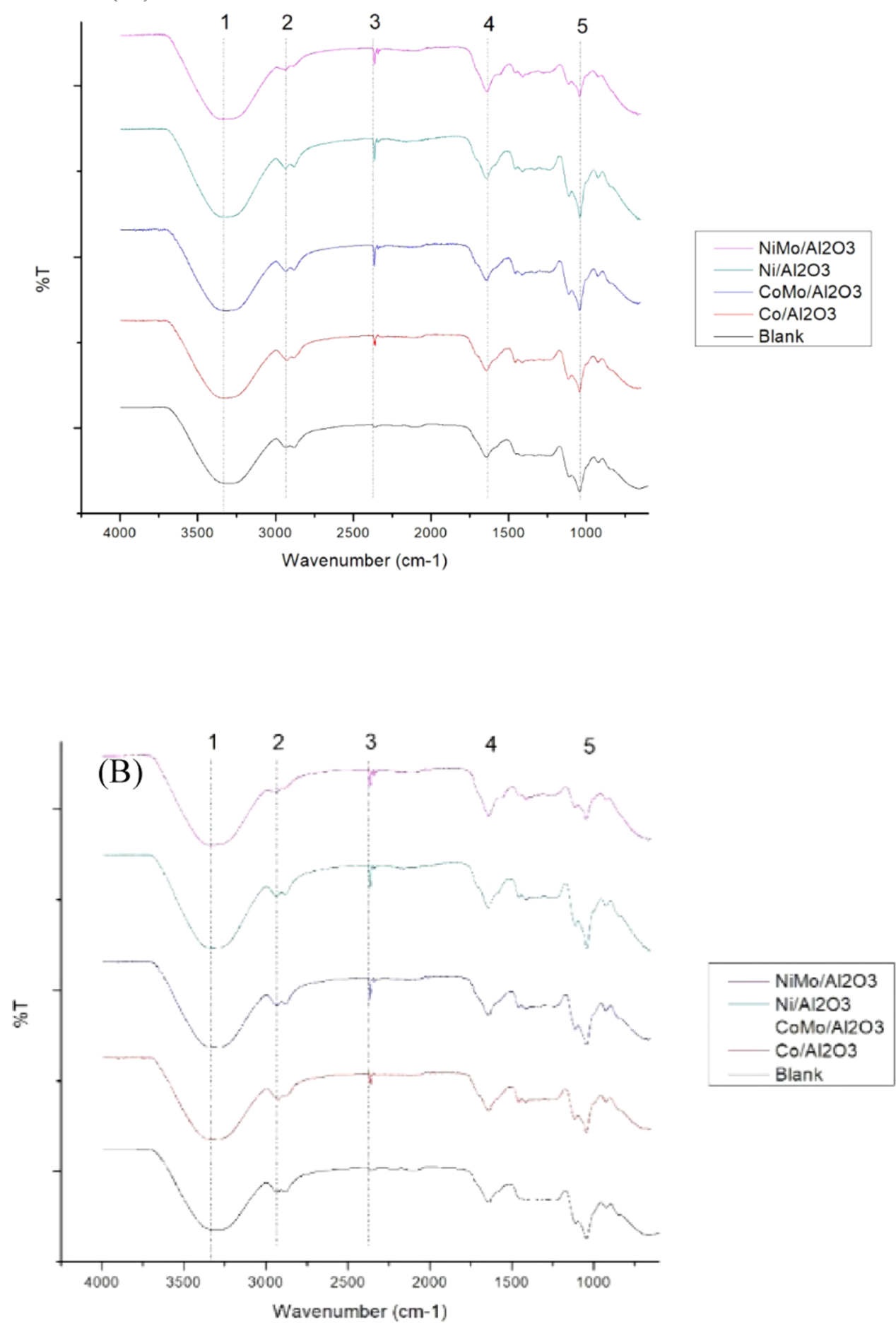

Figure 7. FT-IR analysis of hydrodeoxygenated bio-oil at (A) $300{ }^{\circ} \mathrm{C}$ and (B) $350{ }^{\circ} \mathrm{C}$ using different catalysts with $2 \mathrm{MPa}$ hydrogen for $1 \mathrm{~h}$.

their composition. A similar work has reported the elimination of oxygen atoms from pyrolysis of bio-oil. ${ }^{55}$

Among all catalysts tested, the remarkable peak intensity near $1043 \mathrm{~cm}^{-1}$ (peak no. 5) attributed to the $-\mathrm{C}-\mathrm{O}$ group of phenols, esters, and ethers is declined in the case of the NiMo/ $\mathrm{Al}_{2} \mathrm{O}_{3}$ catalyst compared with others and the blank for both temperatures $\left(300\right.$ and $350{ }^{\circ} \mathrm{C}$ ) in Figure $7 \mathrm{~A}, \mathrm{~B}$. Moreover, an increase of peak intensity was found to be pronounced at the peak no. 4 in the range of $1602-1656 \mathrm{~cm}^{-1}$ representing the greater amount of the $-\mathrm{C}=\mathrm{C}-$ group of alkenes in upgraded bio-oil from $\mathrm{NiMo} / \mathrm{Al}_{2} \mathrm{O}_{3}$ compared with the blank. Furthermore, the smaller ratio of intensity at 1210 to $1656 \mathrm{~cm}^{-1}$ representing $\mathrm{C}-\mathrm{O}$ stretching of acids and $\mathrm{C}=\mathrm{C}$ stretching of alkenes, respectively, was detected. This demonstrated that the acid content in upgraded bio-oil from $\mathrm{NiMo} / \mathrm{Al}_{2} \mathrm{O}_{3}$ catalyst was considerably less than that from other catalysts and the blank when compared with the alkene content. Smaller peaks at the bands at 970 and $1250 \mathrm{~cm}^{-1}$, assigned to the $\mathrm{C}-\mathrm{O}$ stretching of phenols and alcohols, ${ }^{58}$ were detected in upgraded bio-oils from the $\mathrm{NiMo} / \mathrm{Al}_{2} \mathrm{O}_{3}$ catalyst. Molybdenum plays an important role 
Table 1. Peak Assignment from FT-IR Spectroscopy of Functional Groups of Bio-oil ${ }^{56-58}$

\begin{tabular}{|c|c|c|c|}
\hline peak & $\begin{array}{l}\text { wavenumber } \\
\left(\mathrm{cm}^{-1}\right)\end{array}$ & functional group & class of compound \\
\hline 1 & 3350 & $\mathrm{O}-\mathrm{H}$ stretching & polymeric $\mathrm{O}-\mathrm{H}$ \\
\hline 2 & $\begin{array}{l}2960,2925 \\
2850\end{array}$ & $\begin{array}{c}\mathrm{CH}, \mathrm{CH}_{2} \text { stretching, } \\
\mathrm{C}-\mathrm{H} \text { stretching }\end{array}$ & alkanes \\
\hline 3 & 2354.66 & $\mathrm{C}-\mathrm{O}$ stretching & phenol, alcohols, esters, ether \\
\hline \multirow[t]{5}{*}{4} & $\begin{array}{l}1690-1759 \\
1700\end{array}$ & $\mathrm{C}=\mathrm{O}$ stretching & $\begin{array}{l}\text { ketones, aldehydes, carboxylic } \\
\text { acids, mono-alkyl ester }\end{array}$ \\
\hline & $1602-1656$ & $\mathrm{C}=\mathrm{C}$ stretching & alkenes \\
\hline & 1515 & $\mathrm{C}=\mathrm{C}$ ring stretching & aromatics \\
\hline & 1282,1205 & $\mathrm{C}-\mathrm{O}-\mathrm{C}$ stretching & phenol, ester, ethers \\
\hline & 1240,1260 & $\mathrm{C}-\mathrm{H}$ stretching & aromatics \\
\hline \multirow[t]{5}{*}{5} & $\begin{array}{l}1195,1110 \\
1043\end{array}$ & $\mathrm{C}-\mathrm{O}$ stretching & phenol, ester, ethers \\
\hline & 885 & $\mathrm{C}-\mathrm{H}$ deformation & aromatics \\
\hline & 750 & $\begin{array}{l}\text { adjacent } \mathrm{C}-\mathrm{H} \\
\text { deformation }\end{array}$ & aromatics \\
\hline & 696 & $\begin{array}{l}\text { out-of-plane }=\mathrm{CH} \\
\text { deformation }\end{array}$ & alkenes \\
\hline & 615 & $\begin{array}{l}\text { out-of-plane } \mathrm{O}-\mathrm{H} \\
\text { deformation }\end{array}$ & polymeric $\mathrm{O}-\mathrm{H}$ \\
\hline
\end{tabular}

in $\mathrm{Ni}$ metallic to enhance the reduction of $\mathrm{C}-\mathrm{O}$ in phenols to aromatics as well as alcohols to either alkenes or alkanes in the presence of hydrogen, ${ }^{59}$ but a less effect was observed for Co metallic. Therefore, from FT-IR qualitative analysis, the NiMo/ $\mathrm{Al}_{2} \mathrm{O}_{3}$ catalyst provided significant improvement of bio-oil deoxygenation relative to other catalysts at both temperatures investigated.

The gas chromatography-mass spectrometry (GC-MS) analysis of bio-oil confirmed the FT-IR absorption of chemical constituents in upgraded bio-oil. Figure 8 illustrates the high qualitative composition found in bio-oil. Approximately 10 compounds from both HDO temperatures of 300 and $350{ }^{\circ} \mathrm{C}$, which have high peak area percentage among all peaks, were observed, including ethanol, 1-propanol, propanoic acid, 2methyl-cyclopentanone, 2-methyl-cyclopentene-1-one, 3-methyl-cyclopentene-1-one, phenol, 3,4-dimethyl-cyclopentene-1one, 2,3-dimethyl-cyclopentene-1-one, and 2-methyl phenol as demonstrated in Figure 8A,B. The effect of different catalysts on HDO showed that in the presence of a catalyst, the quantities of lower molecular weight phenolic, ester, and ketone were found compared with the blank without adding the catalyst. At $300{ }^{\circ} \mathrm{C}$, $\mathrm{NiMo} / \mathrm{Al}_{2} \mathrm{O}_{3}$ demonstrated more selective products such as 3methyl-2-cyclopentene-1-one, 2-methyl-2-cyclopentene-1-one, and phenol (Figure 8A). It seems that demethylation and methylation reactions are compatible at this temperature as 2methyl phenol and phenol quantities as well as the relative amount of 2,3-methyl-2-cyclopentene-1-one, 3,4-methyl-2cyclopentene-1-one, 3-methyl-2-cyclopentene-1-one, and 2methyl-2-cyclopentene-1-one were not significantly different. The results from the catalytic reaction support the XRD and XPS characteristics of the catalyst that contained the majority of $\mathrm{MoO}_{3}\left(\mathrm{Mo}^{6+}\right)$ and $\mathrm{MoO}_{2}\left(\mathrm{Mo}^{4+}\right)$ on the $\mathrm{Al}_{2} \mathrm{O}_{3}$ support, which selectively catalyze the demethylation of either guaiacol or $m$ cresol to phenol or benzene. ${ }^{60}$ Although the previous study revealed that $\mathrm{MoO}_{3}$ is more active than $\mathrm{MoO}_{2}$ on $\mathrm{HDO}$ of biomass-derived compounds, oxygen appearance during $\mathrm{HDO}$ could oxidize $\mathrm{MoO}_{2}$ to a more stable $\mathrm{MoO}_{3}$ phase that provides higher selectivity and conversion for preferentially cleaving phenolic $\mathrm{Ph}-\mathrm{OMe}$ bonds over weaker aliphatic $\mathrm{Ph}-\mathrm{O}-\mathrm{Me}$ bonds under low hydrogen pressure and temperature in the range of $320-350{ }^{\circ} \mathrm{C}$. ${ }^{61}$

However, when the HDO temperature was increased to 350 ${ }^{\circ} \mathrm{C}$ as demonstrated in Figure 8B, the presence of Mo in NiMo/ $\mathrm{Al}_{2} \mathrm{O}_{3}$ showed a significant influence on demethylation of 2,3methyl-2-cyclopentene-1-one and 3,4-methyl-2-cyclopentene1-one to generate 3-methyl-2-cyclopentene-1-one and 2-methyl2-cyclopentene-1-one, respectively. This proved that as temperature increased, the relatively larger molecules were prone to bond-breaking and reforming to generate lower molecular cyclopentanone structures. In contrast, $\mathrm{Ni} / \mathrm{Al}_{2} \mathrm{O}_{3}$ substantially enhanced methylation of 2-methyl-2-cyclopentene-1-one to 2,3methyl-2-cyclopentene-1-one with high selectivity. At this temperature, more acids and alcohols were generated, especially from $\mathrm{Co} / \mathrm{Al}_{2} \mathrm{O}_{3}$ and $\mathrm{CoMo} / \mathrm{Al}_{2} \mathrm{O}_{3}$, which led to a worse effect on the bio-oil quality due to high oxygen content and low HHV. This occurrence corresponds to the characteristics of CoMo from XRD and XPS results, which contained a greater composition of $\mathrm{MoO}_{2}\left(\mathrm{Mo}^{4+}\right)$ compared with $\mathrm{NiMo}$, which contained more $\mathrm{MoO}_{3}\left(\mathrm{Mo}^{6+}\right)$ phase. $\mathrm{MoO}_{3}\left(\mathrm{Mo}^{6+}\right)$ is more favorable to selectively catalyze guaiacol and $\mathrm{m}$-cresol to phenol and benzene. Since the bond-dissociation energy analysis of relevant phenolic $\mathrm{C}-\mathrm{O}$ bonds indicates that the bond strengths follow an order of $\mathrm{Ph}-\mathrm{OH}>\mathrm{Ph}-\mathrm{OMe}>\mathrm{Ph}-\mathrm{O}-\mathrm{Ph}>\mathrm{Ph}-\mathrm{O}-$ $\mathrm{Me},{ }^{61}$ therefore $\mathrm{MoO}_{2}\left(\mathrm{Mo}^{4+}\right)$ in $\mathrm{CoMo}$ as well as $\mathrm{CoMoO}_{4}$ seemingly promoted unstable compounds, such as acids, furfural, vanillin, and levoglucosan that were able to be converted into esters, ketones, and saturated phenols ${ }^{62}$ relative to NiMo.

According to Table 2, chemical constituents in bio-oil could be categorized into seven groups, namely, alkanes, acids, alcohols, phenols, esters, aldehydes, and ketones. In upgraded bio-oil without the addition of a catalyst, an equal amount of alcohols and ketones was obtained. Relatively high amount of phenolic compounds was observed due to the breakdown of C$\mathrm{C}$ bonds and ether linkages found in the lignin polymer's side chains, which was the major constituent in bio-oil. ${ }^{63}$ Additionally, the majority of G-phenol products in bio-oil derived from guaiacyl accounted for more than $85 \%$ of the total phenols in both raw and upgraded bio-oil. The major contributing compound was 2-methyl-phenol. In the case of ketone generation, the larger ketone molecules such as cyclopentenone and cyclopentanone were derived from the pyrolysis or liquefaction of hemicellulose or cellulose. The cyclopentanone and cyclopentenone were initially produced from the degradation of sugar, and subsequently, opened bond recombination occurred, while the smaller ketone molecule formation was more complicated.

In fact, the amount of different bio-oil compositions depends on each type of catalyst, and the constituent required in large quantities as a worthy bio-fuel from $\mathrm{HDO}$ is alkane. This consequence is also indicated by high $\mathrm{C} / \mathrm{O}$ ratio and high $\mathrm{HHV}$. Nevertheless, the amount of generated acids and alcohols needs to be concerned as it mainly causes corrosion and deterioration of combustion engines. In this work, Figure 9 demonstrates the relative quantity of each group present in bio-oil products from different catalysts and HDO temperatures. As shown in Figure $9 \mathrm{~A}$, the results indicated that the aromatic ketones were the main components from $\mathrm{HDO}$ at $300{ }^{\circ} \mathrm{C}$, followed by alcohols, acids, and alkanes from most catalysts. Among ketone products (Table S2), cyclopentanone and cyclopentene were the main olefins found in hydrodeoxygenated bio-oil derived from liquefied EFB. From GC-MS analysis, it was observed that cyclopentene was 

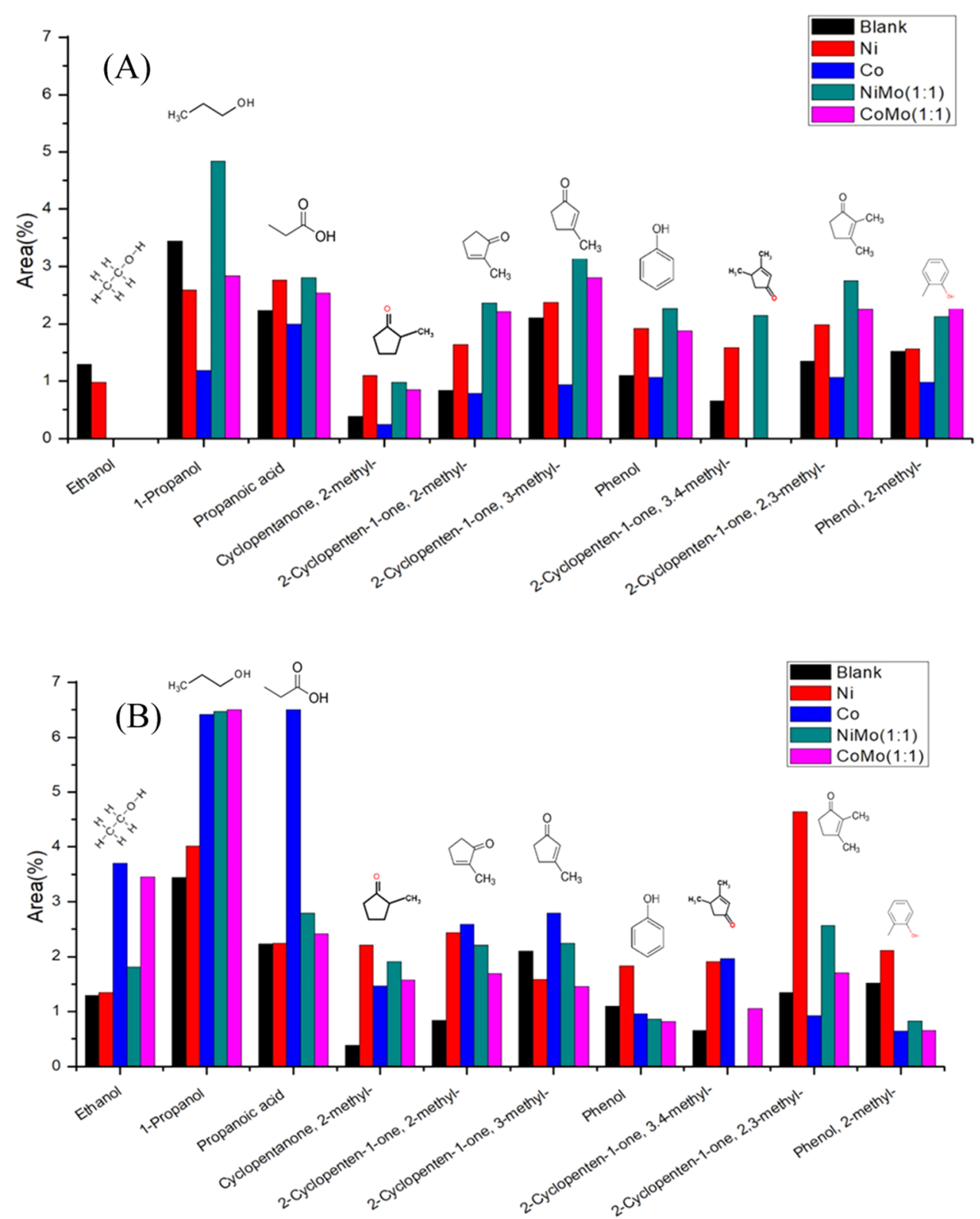

Figure 8. High abundance of chemicals found in upgraded bio-oil from $\mathrm{HDO}$ with various catalysts at (A) $300{ }^{\circ} \mathrm{C}$, and (B) $350{ }^{\circ} \mathrm{C}$ with $2 \mathrm{MPa}$ hydrogen for $1 \mathrm{~h}$.

first generated and subsequently converted into cyclopentanone under the hydrogenation reaction. Cyclopentanone is an important lignocellulosic platform compound derived from degradation products of hydrolysis-dehydration of cellulose and hemicellulose. ${ }^{64}$ In recent literatures, ${ }^{65-68}$ it was demonstrated that cyclopentanone can be produced in high carbon yield by the aqueous-phase selective hydrogenation of furfural from the subsequent hydrolysis-dehydration of hemicellulose. ${ }^{69}$ This compound has a cyclic structure and can be used as a building block in the synthesis of jet fuel range cycloalkanes.

Conversion of 3-hydroxycyclopentanone into 2-cyclopentene-1-one and to cyclopentanone was postulated to occur by hydrogenation. The difference in the solubility of the substrate, intermediates, and products, along with the optimum ratio of metals in the synthesized catalyst, plays a crucial role in achieving better yields. ${ }^{70}$ Moreover, it was reported that the solvent and temperature considerably influenced the selectivity of the hydrogenation product of furfural. In an aqueous solution, high selectivity of furfural conversion into cyclopentanone was achieved at $160{ }^{\circ} \mathrm{C}(70 \%)>140{ }^{\circ} \mathrm{C}(3 \%)>120{ }^{\circ} \mathrm{C}(0 \%)$; however, too high temperature $\left(180{ }^{\circ} \mathrm{C}\right)$ also led to $0 \%$ selectivity of cyclopentanone due to further conversion of cyclopentanone into cyclopentanol under a moderate hydrogen pressure $(2-4 \mathrm{MPa}) .^{71} \mathrm{Co} / \mathrm{Al}_{2} \mathrm{O}_{3}$ produced substantially high amount of acids, which was not favorable for bio-oil upgrading. The presence of $\mathrm{Mo}$ in bimetallic $\mathrm{CoMo} / \mathrm{Al}_{2} \mathrm{O}_{3}$ and $\mathrm{NiMo} /$ $\mathrm{Al}_{2} \mathrm{O}_{3}$ catalysts gave significantly higher aromatic ketone composition in bio-oil, which was also satisfactory due to a higher $\mathrm{HHV}$ and $\mathrm{C} / \mathrm{O}$ ratio.

The upgraded bio-oil at $350{ }^{\circ} \mathrm{C}$ (Table S3) contains aromatic ketones as the majority for $\mathrm{Co} / \mathrm{Al}_{2} \mathrm{O}_{3}, \mathrm{Ni} / \mathrm{Al}_{2} \mathrm{O}_{3}$, and $\mathrm{NiMo}$ / $\mathrm{Al}_{2} \mathrm{O}_{3}$ catalysts in respective degrees as shown in Figure 9B. The $\mathrm{Ni} / \mathrm{Al}_{2} \mathrm{O}_{3}$ catalyst in either $\mathrm{NiO}$ or $\mathrm{NiO}(\mathrm{OH})\left(\mathrm{Ni}^{2+}\right)$ form from the XPS and XRD results promoted the generation of a substantial amount of 2-methyl-phenol, which was possibly due to methylation of phenol. Similar findings were reported on the 
Table 2. Chemical Composition in Upgraded Bio-oil from EFB Solvothermolysis Liquefaction

\begin{tabular}{|c|c|c|}
\hline Categories & Chemicals & $\begin{array}{l}\text { Chemical } \\
\text { formula }\end{array}$ \\
\hline \multirow{3}{*}{ Alkane } & 1,4-Dimethylcyclohexane & $\mathrm{C}_{8} \mathrm{H}_{16}$ \\
\hline & 1-Methylethyl-cyclopentane & $\mathrm{C}_{8} \mathrm{H}_{16}$ \\
\hline & 3-Methylene-pentane & $\mathrm{C}_{6} \mathrm{H}_{12}$ \\
\hline \multirow{2}{*}{ Acid } & Acetic acid & $\mathrm{C}_{2} \mathrm{H}_{4} \mathrm{O}_{2}$ \\
\hline & Propanoic acid & $\mathrm{C}_{3} \mathrm{H}_{6} \mathrm{O}_{2}$ \\
\hline \multirow{3}{*}{ Alcohol } & Ethanol & $\mathrm{C}_{2} \mathrm{H}_{6} \mathrm{O}$ \\
\hline & 1-Propanol & $\mathrm{C}_{3} \mathrm{H}_{8} \mathrm{O}$ \\
\hline & 2,3-Dihydro-1,4-benzodioxin-2-ylmethanol & $\mathrm{C}_{9} \mathrm{H}_{10} \mathrm{O}_{3}$ \\
\hline \multirow{3}{*}{ Phenol } & Phenol & $\mathrm{C}_{6} \mathrm{H}_{5} \mathrm{OH}$ \\
\hline & & \\
\hline & 2-methyl-phenol & $\mathrm{C}_{7} \mathrm{H}_{6} \mathrm{OH}$ \\
\hline Ester & 2-Hydroxypropyl propionate & $\mathrm{C}_{6} \mathrm{H}_{12} \mathrm{O}_{3}$ \\
\hline Aldehyde & Acetaldehyde & $\mathrm{C}_{2} \mathrm{H}_{4} \mathrm{O}$ \\
\hline \multirow[t]{8}{*}{ Ketone } & 2-Propanone & $\mathrm{C}_{3} \mathrm{H}_{6} \mathrm{O}$ \\
\hline & 2-Methyl-cyclopentanone & $\mathrm{C}_{6} \mathrm{H}_{10} \mathrm{O}$ \\
\hline & 2-Hydroxy-3-hexanone & $\mathrm{C}_{6} \mathrm{H}_{12} \mathrm{O}$ \\
\hline & 2-Methyl-2-cyclopentene-1-one & $\mathrm{C}_{6} \mathrm{H}_{8} \mathrm{O}$ \\
\hline & 2,5-Hexanedione & $\mathrm{C}_{6} \mathrm{H}_{10} \mathrm{O}_{2}$ \\
\hline & 3-Methyl-2-cyclopentene-1-one & $\mathrm{C}_{6} \mathrm{H}_{8} \mathrm{O}$ \\
\hline & 3,4-Dimethyl-2-cyclopentene-1-one & $\mathrm{C}_{7} \mathrm{H}_{10} \mathrm{O}$ \\
\hline & 2,3-Dimethyl-2-cyclopentene-1-one & $\mathrm{C}_{7} \mathrm{H}_{10} \mathrm{O}$ \\
\hline
\end{tabular}

decrease of guaiacol and 1,2-benzenediol after HDO since they were converted into cyclohexanone and aromatic HCs such as biphenyl, 1,2,3,4-tetrahydro-5,6-dimethyl-naphthalene, hexamethyl benzene, and 1,3-dimethyl-1-cyclohexene via $\mathrm{CH}_{3}$ substitution, dehydration, or methyltransfer reactions. ${ }^{72}$ An enhancement of $\mathrm{H}_{2}$ availability in the reaction liquid by augmenting $\mathrm{H}_{2}$ pressure or the addition of a $\mathrm{H}_{2}$ donor solvent significantly promotes the transformation of guaiacol into fully deoxygenated products via $\mathrm{HDO}$ with high efficiency. ${ }^{73}$

A significantly higher quantity of alkane was also found in the $\mathrm{Co} / \mathrm{Al}_{2} \mathrm{O}_{3}$ catalyst at this temperature with a smaller amount of acids compared with the upgraded bio-oil at $300{ }^{\circ} \mathrm{C}$. This was a favorable consequence; however, the upgraded bio-oil yield from the $\mathrm{Co} / \mathrm{Al}_{2} \mathrm{O}_{3}$ catalyst (27 wt \%) was the lowest among all catalysts. Moreover, upgraded bio-oil from $\mathrm{CoMo} / \mathrm{Al}_{2} \mathrm{O}_{3}$ and
$\mathrm{NiMo} / \mathrm{Al}_{2} \mathrm{O}_{3}$ catalysts generated high amount of unidentified substances, which may contain high HHVs with low oxygen content. Accordingly, the $\mathrm{C} / \mathrm{O}$ ratio and energy ratio, in which the yield and HHV were taken into account, should be considered for the finest selection of HDO conditions for upgrading bio-oil from EFB liquefaction.

Based on the GC-MS results, the HDO of the main product in bio-oil derived from liquefaction of EFB catalyzed by the NiMo/ $\mathrm{Al}_{2} \mathrm{O}_{3}$ catalyst is demonstrated in Figure 10. The main reactions of guaiacol-like compounds included (1) demethylation reactions of the $\mathrm{CH}_{3} \mathrm{O}$ group by the hydrogenolysis of the $\mathrm{O}-$ $\mathrm{CH}_{3}$ bond of the methoxy group, or demethoxylation via the cleavage of the $\mathrm{C}_{\text {aromatic }}-\mathrm{OCH}_{3}$ bond, and (2) in the case of phenolic $\mathrm{OH}$-group the first conversion pathway is the hydrogenolysis of the $\mathrm{C}_{\text {aromatic }}-\mathrm{OH}$ bond, while the second 

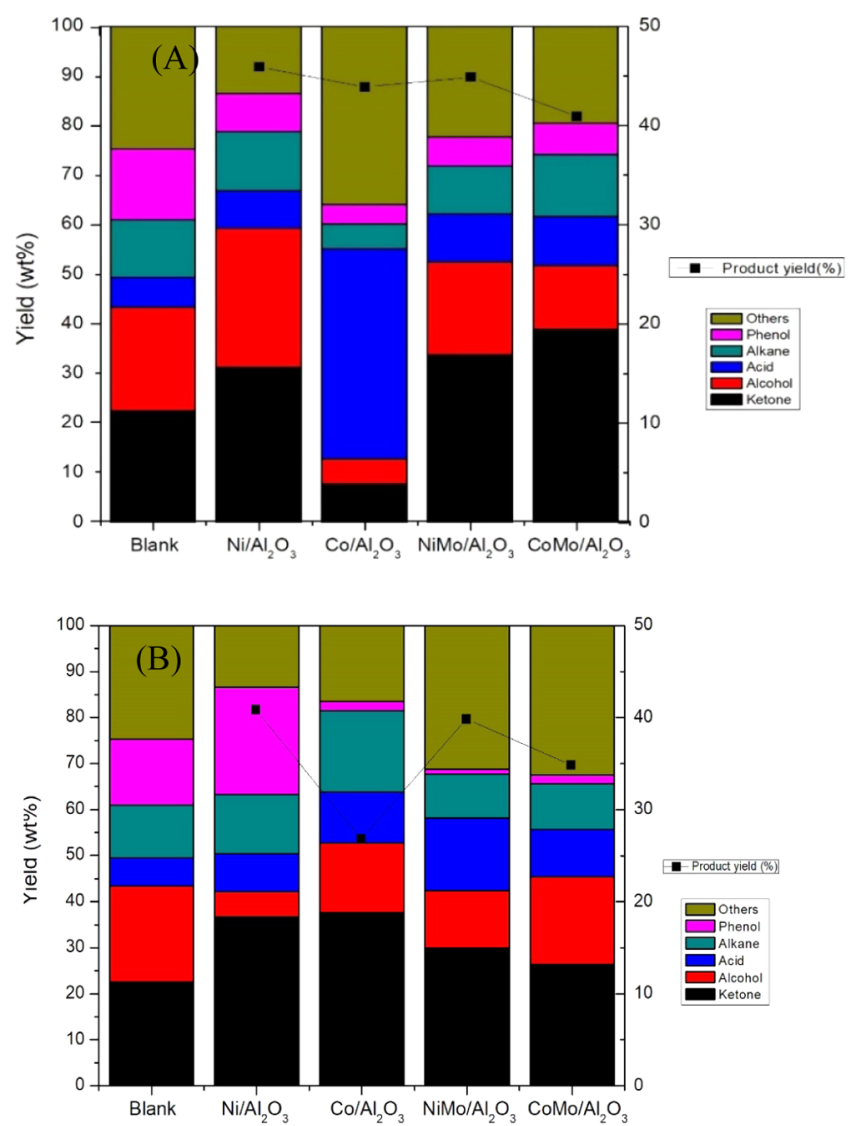

Figure 9. Chemical compositions of bio-oils from $\mathrm{HDO}$ with $2 \mathrm{MPa}$ hydrogen for $1 \mathrm{~h}$ in the presence of different catalysts at (A) $300{ }^{\circ} \mathrm{C}$ and (B) $350{ }^{\circ} \mathrm{C}$.

pathway involves the hydrogenation of the initial aromatic ring followed by the $\mathrm{OH}$-group elimination. ${ }^{74}$ The ability of a metallic Ni-based catalyst for a slightly inferior concentration of protons in the aromatic region has been reported, indicating higher activity toward hydrogenation of the aromatic rings in bio-oil, similar to a $\mathrm{Ru} / \mathrm{C}$-based catalyst. ${ }^{75}$ In the present study, the appearance of the $\mathrm{NiO}$ or $\mathrm{NiO}(\mathrm{OH})$ phase from $\mathrm{XRD}$ and XPS results also indicated the ability of oxygen adsorption toward the cleavage of aromatic rings promoted by the presence of $\mathrm{Mo}$ in the $\mathrm{NiMo} / \mathrm{Al}_{2} \mathrm{O}_{3}$ catalyst. The incorporation of nickel and molybdenum in the synthesized catalyst with a proper $\mathrm{Ni}$ / Mo ratio as well as hydrogen partial pressure and temperature substantially influences the ring-opening reaction in the hydrogenation process, attributable to new acid sites associated with the molybdenum species. ${ }^{76}$

Previous reports on the recyclability study of $\mathrm{NiMo} / \mathrm{Al}_{2} \mathrm{O}_{3}$ and $\mathrm{CoMo} / \mathrm{Al}_{2} \mathrm{O}_{3}$ catalysts stated that the $\mathrm{HDO}$ reactivity of NiMo and CoMo on the $\mathrm{Al}_{2} \mathrm{O}_{3}$ support could be substantially enhanced after the first recycle compared with the fresh catalyst in the presence of hydrocarbons containing high sulfur content. ${ }^{77}$ High stability up to five times of the spent catalyst for oil upgrading at $400{ }^{\circ} \mathrm{C}$, an initial $\mathrm{H}_{2}$ pressure of $5 \mathrm{MPa}$, and $800 \mathrm{rpm}$ for $1 \mathrm{~h}$ reaction could be obtained. Recovery of metals from spent hydrotreated catalysts could be efficiently done by mineral phase reconstruction using sodium carbonate and carbon powder followed by stepwise extraction. The leaching ability of $\mathrm{Al}$ and Mo was modulated by different ratios of substances added, the solid-to-liquid ratio, and temperature and time. $^{78}$

2.2.2. Ultimate Compositional Analysis of Hydrodeoxygenated Bio-oil. The amount of elemental $\mathrm{C}, \mathrm{H}, \mathrm{N}$, and $\mathrm{O}$, which are components in bio-oil before and after the HDO process using different catalysts and temperatures, is shown in Table 3. The raw bio-oil derived from EFB solvothermolysis liquefaction contained $\mathrm{C}, \mathrm{H}, \mathrm{N}$, and $\mathrm{O}$ contents of $30.8,9.1,6.4$, and $42.3 \mathrm{wt} \%$, respectively. A higher nitrogen content in crude bio-oil was obtained when compared with raw EFB since the pressurized nitrogen gas was applied during biomass liquefaction $\left(300{ }^{\circ} \mathrm{C}, 8 \mathrm{MPa} \mathrm{N}_{2}\right.$ for $\left.1 \mathrm{~h}\right)$. Another carbon yield of approximately $50 \mathrm{wt} \%$ was in heavy oil, which was not included in this study.

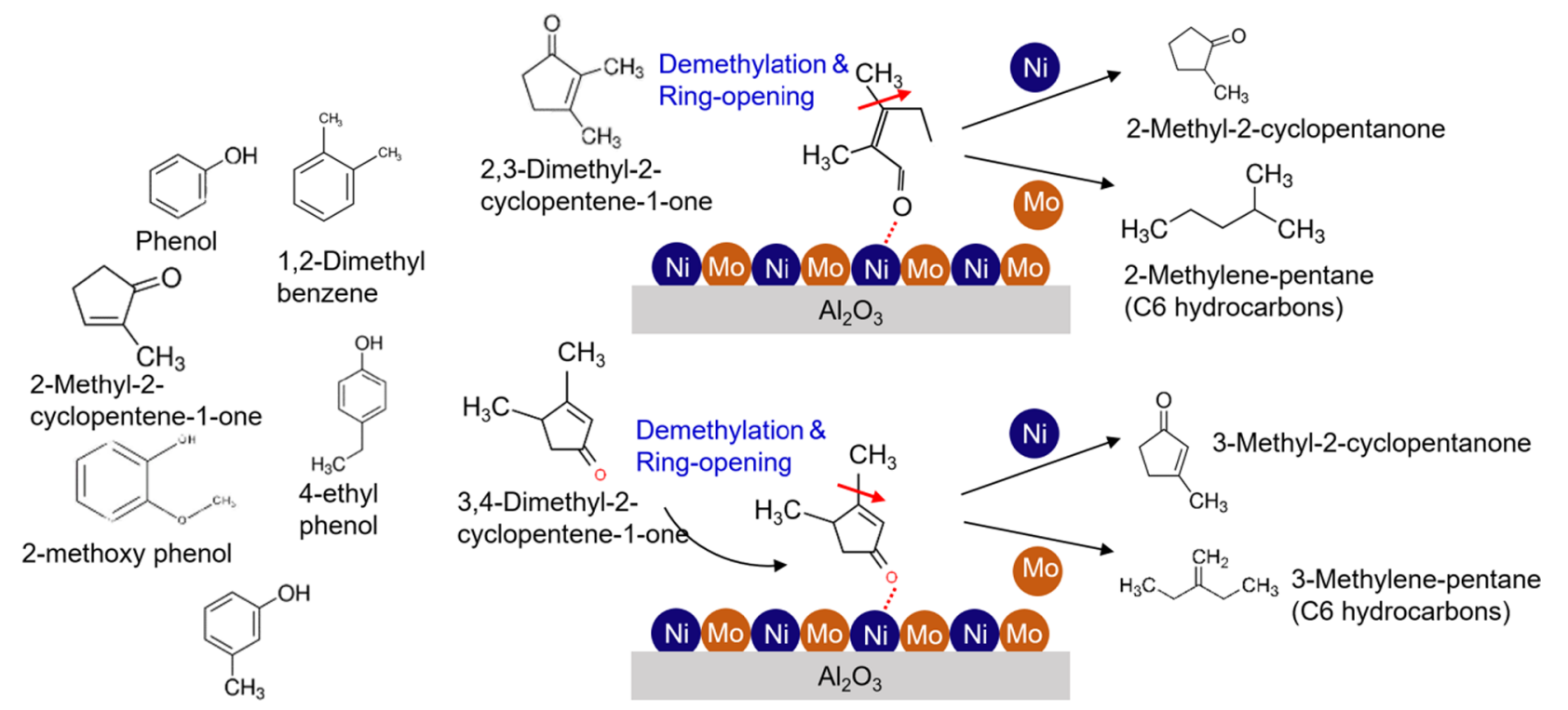

Figure 10. Proposed schematic mechanism of demethylation and the ring-opening reaction of 2,3-and 3,4-dimethylbenzene catalyzed by the NiMo/ $\mathrm{Al}_{2} \mathrm{O}_{3}$ catalyst. 
Table 3. Elemental Analysis and Carbon Yield from Hydrodeoxygenation of Bio-oil at Different Temperatures and in the Presence of Different Catalysts

\begin{tabular}{|c|c|c|c|c|c|c|c|c|c|c|c|c|}
\hline \multirow[b]{2}{*}{ substrate } & \multirow{2}{*}{\multicolumn{2}{|c|}{$\begin{array}{l}\text { upgrading condition } \\
\text { (temperature, catalysts) }\end{array}$}} & \multicolumn{5}{|c|}{ elemental content of light bio-oil (wt \%) } & \multicolumn{3}{|c|}{ elemental ratio } & \multirow[b]{2}{*}{$\begin{array}{l}\text { bio-oil yield } \\
\text { (wt \%) }\end{array}$} & \multirow[b]{2}{*}{$\begin{array}{c}\text { carbon } \\
\text { yield }^{a}(\%)\end{array}$} \\
\hline & & & $\mathrm{C}$ & $\mathrm{H}$ & $\mathrm{N}$ & $\mathrm{O}$ & S & $\begin{array}{c}\mathrm{H} / \mathrm{O}(\mathrm{by} \\
\mathrm{mol})\end{array}$ & $\begin{array}{c}\mathrm{H} / \mathrm{C}(\mathrm{by} \\
\mathrm{mol})\end{array}$ & $\begin{array}{c}\mathrm{C} / \mathrm{O}(\mathrm{by} \\
\mathrm{mol})\end{array}$ & & \\
\hline raw EFB & na ${ }^{b}$ & & 42.25 & 5.88 & 1.03 & 50.75 & 0.09 & 1.85 & 1.67 & 1.11 & na & 100 \\
\hline $\begin{array}{l}\text { raw bio-oil from EFB } \\
\text { liquefaction }\end{array}$ & na & & 30.81 & 9.1 & 6.36 & 42.27 & na & 3.44 & 3.54 & 0.97 & 61.41 & 44.78 \\
\hline \multirow[t]{8}{*}{ upgraded bio-oil } & $300{ }^{\circ} \mathrm{C}$ & $\mathrm{Ni} / \mathrm{Al}_{2} \mathrm{O}_{3}$ & 28.84 & 9.56 & 5.9 & 48.1 & na & 3.18 & 3.98 & 0.80 & 46 & 43.06 \\
\hline & & $\mathrm{Co} / \mathrm{Al}_{2} \mathrm{O}_{3}$ & 27.37 & 9.62 & 5.52 & 55.74 & na & 2.76 & 4.22 & 0.65 & 44 & 41.76 \\
\hline & & $\mathrm{NiMo} / \mathrm{Al}_{2} \mathrm{O}_{3}$ & 25.44 & 9.66 & 5.94 & 41.05 & na & 3.77 & 4.56 & 0.83 & 45 & 41.83 \\
\hline & & $\mathrm{CoMo} / \mathrm{Al}_{2} \mathrm{O}_{3}$ & 26.2 & 9.43 & 6.3 & 49.77 & na & 3.03 & 4.32 & 0.70 & 41 & 42.22 \\
\hline & $350{ }^{\circ} \mathrm{C}$ & $\mathrm{Ni} / \mathrm{Al}_{2} \mathrm{O}_{3}$ & 23.96 & 10.42 & 4.77 & 44.1 & na & 3.78 & 5.22 & 0.72 & 41 & 37.49 \\
\hline & & $\mathrm{Co} / \mathrm{Al}_{2} \mathrm{O}_{3}$ & 29.66 & 10.27 & 4.02 & 49.43 & na & 3.32 & 4.16 & 0.80 & 27 & 33.42 \\
\hline & & $\mathrm{NiMo} / \mathrm{Al}_{2} \mathrm{O}_{3}$ & 37.69 & 10.77 & 4.96 & 38.91 & na & 4.43 & 3.43 & 1.29 & 40 & 50.83 \\
\hline & & $\mathrm{CoMo} / \mathrm{Al}_{2} \mathrm{O}_{3}$ & 38.21 & 10.3 & 4.01 & 35.11 & na & 4.69 & 3.23 & 1.45 & 35 & 35.48 \\
\hline
\end{tabular}

${ }^{a}$ In this work, the carbon yield was calculated from only the light bio-oil portion and the heavy oil portion was excluded. ${ }^{b}$ na $=$ not applicable.

Table 4. High Heating Value (HHV) and Energy Ratio of All Upgraded Bio-oils from Hydrodeoxygenation at Different Temperatures and in the Presence of Different Catalysts ${ }^{a}$

\begin{tabular}{|c|c|c|c|c|c|c|c|c|c|c|}
\hline \multirow[b]{2}{*}{ biomass } & \multirow{2}{*}{\multicolumn{2}{|c|}{$\begin{array}{l}\text { upgrading condition } \\
\text { (temperature, catalysts) }\end{array}$}} & \multirow[b]{2}{*}{$\begin{array}{l}\text { HHV of raw material } \\
\qquad\left(\mathrm{MJ} \mathrm{kg}^{-1}\right)\end{array}$} & \multicolumn{3}{|c|}{ light bio-oil } & \multicolumn{3}{|c|}{ heavy bio-oil } & \multirow[b]{2}{*}{$\begin{array}{l}\text { total energy } \\
\text { ratio }(r)\end{array}$} \\
\hline & & & & $\begin{array}{c}\text { yield } \\
(\%)\end{array}$ & $\begin{array}{c}\mathrm{HHV} \\
\left(\mathrm{MJ} \mathrm{kg}^{-1}\right)\end{array}$ & $\begin{array}{l}\text { energy } \\
\text { ratio }(r)\end{array}$ & $\begin{array}{c}\text { yield } \\
(\%)\end{array}$ & $\begin{array}{c}\mathrm{HHV} \\
\left(\mathrm{MJ} \mathrm{kg}^{-1}\right)\end{array}$ & $\begin{array}{l}\text { energy } \\
\text { ratio }(r)\end{array}$ & \\
\hline $\begin{array}{l}\text { raw bio-oil from EFB } \\
\text { liquefaction }\end{array}$ & $\mathrm{na}^{b}$ & & 13.02 & 61 & 36.67 & 1.73 & 15.39 & 40.56 & 0.48 & 2.21 \\
\hline \multirow[t]{8}{*}{ upgraded bio-oil } & $300{ }^{\circ} \mathrm{C}$ & $\mathrm{Ni} / \mathrm{Al}_{2} \mathrm{O}_{3}$ & 13.02 & 46 & 38.77 & 1.37 & 15.39 & 40.56 & 0.48 & 1.85 \\
\hline & & $\mathrm{Co} / \mathrm{Al}_{2} \mathrm{O}_{3}$ & 13.02 & 44 & 39.88 & 1.35 & 15.39 & 40.56 & 0.48 & 1.83 \\
\hline & & $\mathrm{NiMo} / \mathrm{Al}_{2} \mathrm{O}_{3}$ & 13.02 & 45 & 39.15 & 1.35 & 15.39 & 40.56 & 0.48 & 1.83 \\
\hline & & $\mathrm{CoMo} / \mathrm{Al}_{2} \mathrm{O}_{3}$ & 13.02 & 41 & 39.57 & 1.25 & 15.39 & 40.56 & 0.48 & 1.73 \\
\hline & $350{ }^{\circ} \mathrm{C}$ & $\mathrm{Ni} / \mathrm{Al}_{2} \mathrm{O}_{3}$ & 13.02 & 41 & 40.07 & 1.26 & 15.39 & 40.56 & 0.48 & 1.74 \\
\hline & & $\mathrm{Co} / \mathrm{Al}_{2} \mathrm{O}_{3}$ & 13.02 & 27 & 42.53 & 0.88 & 15.39 & 40.56 & 0.48 & 1.36 \\
\hline & & $\mathrm{NiMo} / \mathrm{Al}_{2} \mathrm{O}_{3}$ & 13.02 & 41 & 40.87 & 1.29 & 15.39 & 40.56 & 0.48 & 1.77 \\
\hline & & $\mathrm{CoMo} / \mathrm{Al}_{2} \mathrm{O}_{3}$ & 13.02 & 35 & 41.33 & 1.11 & 15.39 & 40.56 & 0.48 & 1.59 \\
\hline
\end{tabular}

${ }^{a}$ Note: The energy ratio was calculated based on the HHV of raw EFB at $13.02 \mathrm{MJ} \mathrm{kg}{ }^{-1}$ for all cases. ${ }^{b}$ na $=$ not applicable.

From the results, oxygen reduction was significantly observed from $\mathrm{HDO}$ at $350{ }^{\circ} \mathrm{C}$ from $\mathrm{NiMo} / \mathrm{Al}_{2} \mathrm{O}_{3}$ and $\mathrm{CoMo} / \mathrm{Al}_{2} \mathrm{O}_{3}$ catalysts indicated by higher $\mathrm{H} / \mathrm{O}$ and $\mathrm{C} / \mathrm{O}$ ratios. It was found that the oxygen content decreased from 42.3 to $38.9 \%$, corresponding to $7.9 \%$ oxygen removal after the HDO catalyzed by the $\mathrm{NiMo} / \mathrm{Al}_{2} \mathrm{O}_{3}$ catalyst at $350{ }^{\circ} \mathrm{C}$. The decreased oxygen content is the result of decarbonylation/decarboxylation to generate steam, $\mathrm{CO}$, and $\mathrm{CO}_{2} \cdot{ }^{7272}$ In addition, it was found that after the HDO process in all conditions, the hydrogen content was increased. This shows that the hydrogenation/hydrogenolysis of bio-oil occurs during the HDO process.

The $\mathrm{H} / \mathrm{O}, \mathrm{H} / \mathrm{C}$, and $\mathrm{O} / \mathrm{C}$ ratios can be used as the indicators of the hydrogenation and deoxygenation processes for upgrading oxygenated oil for the replacement of petroleum fuels. Considering the conventional fuels such as diesel and fatty acid methyl ester, ${ }^{79}$ the ultimate goal of hydrogenation is to achieve the liquid product with $\mathrm{O} / \mathrm{C}$ and $\mathrm{H} / \mathrm{C}$ ratios ranging from 1.5 to $2.0 .^{23}$ These values correspond to $0.5-0.7$ of the $\mathrm{C} /$ $\mathrm{O}$ ratio. In Table 3 , the results in this study showed that all of the upgraded bio-oils from HDO of EFB-derived bio-oil have higher $\mathrm{C} / \mathrm{O}$ ratios than the target due to successful oxygen reduction and hydrogenation. In particular, $\mathrm{HDO}$ catalyzed by $\mathrm{CoMo} /$ $\mathrm{Al}_{2} \mathrm{O}_{3}$ and $\mathrm{NiMo} / \mathrm{Al}_{2} \mathrm{O}_{3}$ catalysts at $350{ }^{\circ} \mathrm{C}$ gave the upgraded bio-oil with $\mathrm{C} / \mathrm{O}$ ratios at 1.45 and 1.29 , respectively, which were substantially greater than those at other conditions. These values corresponded to $\mathrm{O} / \mathrm{C}$ ratios of $0.69-0.78$, which were still higher than those of upgraded liquefied bio-oil from cornstalk by catalytic hydrodeoxygenation using bimetallic ammonium nickel molybdate at different temperatures (280$370{ }^{\circ} \mathrm{C}$ ) under supercritical ethanol with initial $4 \mathrm{MPa}_{2}, 60$ min, giving $\mathrm{H} / \mathrm{C}$ and $\mathrm{O} / \mathrm{C}$ molar ratios of upgraded bio-oil in the range of $1.19-1.30$ and $0.05-0.15$, respectively, depending on temperatures. ${ }^{80}$ Furthermore, upgraded bio-oil from the NiMo/ $\mathrm{Al}_{2} \mathrm{O}_{3}$ catalyst at $350^{\circ} \mathrm{C}$ gave the highest carbon yield of $50.83 \%$; therefore, it was considered the most promising catalyst in this work.

2.2.3. HHV of Hydrodeoxygenated Bio-oil. The HHVs of the bio-oil from $\mathrm{HDO}$ using four different catalysts at 300 and 350 ${ }^{\circ} \mathrm{C}$ are shown in Table 4. It was found that the $\mathrm{HHV}$ values from $\mathrm{HDO}$ at $300{ }^{\circ} \mathrm{C}$ catalyzed by $\mathrm{Ni} / \mathrm{Al}_{2} \mathrm{O}_{3}, \mathrm{Co} / \mathrm{Al}_{2} \mathrm{O}_{3}, \mathrm{NiMo} /$ $\mathrm{Al}_{2} \mathrm{O}_{3}$, and $\mathrm{CoMo} / \mathrm{Al}_{2} \mathrm{O}_{3}$ catalysts were $38.77,39.88,39.15$, and $39.57 \mathrm{MJ} \mathrm{kg}^{-1}$, respectively. Among all catalysts investigated at $300{ }^{\circ} \mathrm{C}$, deoxygenated bio-oil catalyzed by the $\mathrm{Co} / \mathrm{Al}_{2} \mathrm{O}_{3}$ catalyst gave the highest $\mathrm{HHV}$; however, the value was insignificantly different compared with those of the other catalysts.

Bio-oil $\mathrm{HDO}$ at $350{ }^{\circ} \mathrm{C}$ using $\mathrm{Ni} / \mathrm{Al}_{2} \mathrm{O}_{3}, \mathrm{Co} / \mathrm{Al}_{2} \mathrm{O}_{3}, \mathrm{NiMo} /$ $\mathrm{Al}_{2} \mathrm{O}_{3}$, and $\mathrm{CoMo} / \mathrm{Al}_{2} \mathrm{O}_{3}$ catalysts gave superior $\mathrm{HHVs}$ of 40.07 , 42.53, 40.87, and 41.33 $\mathrm{MJ} \mathrm{kg}^{-1}$, respectively, compared with those under $\mathrm{HDO}$ at $300{ }^{\circ} \mathrm{C}$. At $350{ }^{\circ} \mathrm{C}$, deoxygenated bio-oil from $\mathrm{HDO}$ in the presence of $\mathrm{Co} / \mathrm{Al}_{2} \mathrm{O}_{3}$ had the highest $\mathrm{HHV}$ value, but the lowest yield was obtained after the deoxygenation reaction. This corresponded to the previous report stating that the yield of the product decreased when the HDO temperature and time of heating increased. ${ }^{81}$ In the presence of a catalyst, 
more gaseous products are generated during the deoxygenation reaction at high temperature and thus a significantly lower yield was obtained. A higher HHV of bio-oil was achieved as a result of oxygen reduction in the upgraded bio-oil. During HDO, a promising catalyst could lead the favorable reactions that allow $\mathrm{C}=\mathrm{C}$ bonds $\left(614 \mathrm{~kJ} \mathrm{~mol}^{-1}\right)$ and $\mathrm{C}-\mathrm{O}$ bonds $\left(358 \mathrm{~kJ} \mathrm{~mol}^{-1}\right)$ to break apart by hydrotreatment, while new $\mathrm{C}-\mathrm{C}$ bonds $(348 \mathrm{~kJ}$ $\mathrm{mol}^{-1}$ ) and $\mathrm{C}-\mathrm{H}$ bonds $\left(413 \mathrm{~kJ} \mathrm{~mol}^{-1}\right)$ are formed during hydrogenolysis. ${ }^{82}$ Long-chain alkane products from $\mathrm{HDO}$ in the presence of the $\mathrm{Co} / \mathrm{Al}_{2} \mathrm{O}_{3}$ catalyst at $350{ }^{\circ} \mathrm{C}$ generated the upgraded bio-oil with a substantially greater $\mathrm{HHV}$ as shown in Table 4. Table S4 shows the comparison of $\mathrm{O} / \mathrm{C}$ and $\mathrm{H} / \mathrm{C}$ ratios, HHVs, and main products from hydrodeoxygenation (HDO) of bio-oil using $\mathrm{Ni}$ - and Co-based catalysts from this study and previous studies.

A higher HHV of the bio-oil implies a higher portion of the energy in the feed that turns into the bio-oil. However, after deoxygenation of light bio-oil, a lower yield was obtained due to the loss of low-molecular-weight compounds into gaseous products. Thus, a more complete measurement of the process in delivering energy from biomass to the bio-oil is the energy ratio $(r)$. This value includes the mass yield and HHV of bio-oil and is calculated relative to the HHV of raw material. According to the results, Table 4 shows that the $\mathrm{NiMo} / \mathrm{Al}_{2} \mathrm{O}_{3}$ catalyst in $\mathrm{HDO}$ at $350{ }^{\circ} \mathrm{C}$ was the most promising catalyst and condition that produced deoxygenated bio-oil with markedly high energy ratios. Moreover, this condition provided the greatest carbon yield as well as the highest ratios of $\mathrm{C} / \mathrm{O}, \mathrm{H} / \mathrm{C}$, and $\mathrm{H} / \mathrm{O}$ (Table 3 ), indicating the good quality of bio-fuel for combustion engines. Previous reports also confirmed that metallic $\mathrm{Ni}$ and $\mathrm{Co}$ are active in $\mathrm{C}-\mathrm{C}$ bond hydrogenolysis ${ }^{17,83}$ and thus give rather a worse effect since the increased hydrogen consumption and the decreased carbon yield were obtained. Moreover, sole metallic $\mathrm{Ni}$ and Co suppressed the hydrogenation of benzene rings. Therefore, the interaction of a second metal promoter as a bimetallic catalyst such as Mo has been proposed. ${ }^{84}$ The HDO with the $\mathrm{NiMo} / \mathrm{Al}_{2} \mathrm{O}_{3}$ catalyst at $350{ }^{\circ} \mathrm{C}$ produced the highest quality of upgraded bio-oil derived from EFB liquefaction with the least release of $\mathrm{SO}_{x}$ and $\mathrm{NO}_{x}$ with high $\mathrm{HHV}$.

\section{CONCLUSIONS}

Upgrading bio-oil from solvothermolysis liquefaction of a palm empty fruit bunch by catalytic HDO in the presence of monometallic $\mathrm{Ni}$ and $\mathrm{Co}$ and bimetallic NiMo and CoMo over an alumina support was investigated at different temperatures of 300 and $350{ }^{\circ} \mathrm{C}$. From the results, HDO catalyzed by NiMo/ $\mathrm{Al}_{2} \mathrm{O}_{3}$ at $350{ }^{\circ} \mathrm{C}$ gave the highest bio-oil yield. Apart from that, $\mathrm{HDO}$ in the presence of the $\mathrm{NiMo} / \mathrm{Al}_{2} \mathrm{O}_{3}$ catalyst at $350{ }^{\circ} \mathrm{C}$ generated bio-oil with the greatest energy ratio, carbon yield, and highest ratios of $\mathrm{C} / \mathrm{O}, \mathrm{H} / \mathrm{C}$, and $\mathrm{H} / \mathrm{O}$, indicating the good quality of bio-fuel for combustion engines with the least release of $\mathrm{SO}_{x}$ and $\mathrm{NO}_{x}$. Cyclopentanone, cyclopentene and related compounds were the main olefins found in hydrodeoxygenated bio-oil derived from liquefied EFB. These compounds are building blocks for the synthesis of jet fuel range cycloalkanes. Interestingly, these catalysts work effectively without sulfidation processes that could incorporate sulfur into bio-oil composition, which leads to environmental problems. The findings provide a competent alternative for thermochemical conversion of wet biomass into liquid fuels in an energy-efficient approach.

\section{EXPERIMENTAL SECTION}

4.1. Materials. To produce bio-oil, a palm empty fruit bunch (EFB) was selected as a raw material for solvothermolysis liquefaction. EFB is the most abundant solid residue accounting for $20 \mathrm{wt} \%$ of fresh palm bunch including fruits. EFB biomass is produced at approximately $4.42 \mathrm{t} \mathrm{ha}^{-1}$ year ${ }^{-1}$ after oil extraction at palm oil mills. ${ }^{85}$ EFB was obtained from Chumporn Palm Oil Industry Public Company Limited (CPI), Thailand. The precursors for catalyst preparation, namely, $\mathrm{Ni}\left(\mathrm{NO}_{3}\right)_{2} \cdot 6 \mathrm{H}_{2} \mathrm{O}$, $\mathrm{Co}\left(\mathrm{NO}_{3}\right)_{2} \cdot 6 \mathrm{H}_{2} \mathrm{O},\left(\mathrm{NH}_{4}\right)_{6} \mathrm{Mo}_{7} \cdot 4 \mathrm{H}_{2} \mathrm{O}$, and the alumina support were purchased from Sigma-Aldrich.

4.2. Microwave-Assisted Torrefaction and Solvothermolysis Liquefaction of EFB. The EFB sample was initially washed with tap water and dried in an oven at $105^{\circ} \mathrm{C}$ for $12 \mathrm{~h}$ before crushing and milling to a consistent particle size of $+50 /-$ 200 mesh by sieving. The moisture content of the feedstock was determined by a moisture analyzer (Ohaus MB120). Prior to biomass liquefaction, $2 \mathrm{~g}$ of biomass was mixed with $20 \mathrm{~mL}$ of glycerol and subjected to microwave irradiation (Anton Paar, Austria) at $800 \mathrm{~W}$ for $20 \mathrm{~min}$ with a heating-up duration of 2 min. Five reaction vessels were used simultaneously. Microwave energy is able to couple with the molecules in a pretreatment mixture to provide more volumetric and energy-efficient internal heating of a substrate. ${ }^{86}$

After microwave pretreatment, the solvothermolysis liquefaction was performed in a $500 \mathrm{~mL}$ reactor. In the experiment, $100 \mathrm{~mL}$ of the microwave-treated slurry and $1 \mathrm{~g}$ of the $\mathrm{Na}_{2} \mathrm{CO}_{3}$ catalyst ( $1 \mathrm{wt} \%)$ were mixed in the reactor. The reactants were agitated using an external stirrer at $150 \mathrm{rpm}$ equipped with a magnetic seal drive. The temperature was controlled at $300{ }^{\circ} \mathrm{C}$ (heating rate was $10^{\circ} \mathrm{C} \mathrm{min}^{-1}$ ), and nitrogen gas was applied to set the initial pressure at $8 \mathrm{MPa}$. After $1 \mathrm{~h}$ reaction was completed, the reactor was cooled down to room temperature by a cooling water system.

Heavy bio-oil and light bio-oil were generated after biomass liquefaction, and they were separated by a separation funnel. Ultimate analysis was performed using a CHNS/O analyzer, and the high heating value (HHV) of light bio-oil was measured using a bomb calorimeter. The chemical composition of bio-oil was analyzed by gas chromatography-mass spectrometry (GCMS) after liquid-liquid extraction using toluene as an extractant. The methods of preparation and analysis are reported elsewhere. ${ }^{10}$ Light bio-oil was further upgraded using catalytic HDO.

4.3. Catalysts Preparation by the Wet Impregnation Method. Wet impregnation of monometallic and bimetallic catalysts on the alumina support $\left(\mathrm{Al}_{2} \mathrm{O}_{3}\right)$ was selected for catalyst synthesis in this study. Metal precursors for monometallic catalysts $\mathrm{Ni} / \mathrm{Al}_{2} \mathrm{O}_{3}$ and $\mathrm{Co} / \mathrm{Al}_{2} \mathrm{O}_{3}$ were $\mathrm{Ni}\left(\mathrm{NO}_{3}\right)_{2}$. $6 \mathrm{H}_{2} \mathrm{O}\left(290.79 \mathrm{~g} \mathrm{~mol}^{-1}\right)$ and $\mathrm{Co}\left(\mathrm{NO}_{3}\right)_{2} \cdot 6 \mathrm{H}_{2} \mathrm{O}(291.03 \mathrm{~g}$ $\left.\mathrm{mol}^{-1}\right)$, respectively. At $5 \% \mathrm{w} / \mathrm{w}$ loading based on the support, $\mathrm{Ni}\left(\mathrm{NO}_{3}\right)_{2} \cdot 6 \mathrm{H}_{2} \mathrm{O}$ or $\mathrm{Co}\left(\mathrm{NO}_{3}\right)_{2} \cdot 6 \mathrm{H}_{2} \mathrm{O}$ was weighed based on $\mathrm{Al}_{2} \mathrm{O}_{3}$ and dissolved in $5 \mathrm{~mL}$ of deionized (DI) water. The solution was poured dropwise over the dry $\mathrm{Al}_{2} \mathrm{O}_{3}$ support in a crucible and dried at $100{ }^{\circ} \mathrm{C}$ for $12 \mathrm{~h}$. To prevent the particle agglomeration and crystallinity change, the calcination condition selected in this study was $500{ }^{\circ} \mathrm{C}$ for $5 \mathrm{~h}$ in air. ${ }^{87}$ After that, $\mathrm{H}_{2}$-TPR analysis was used to find the optimal temperature for catalyst reduction. Before utilization in the HDO, the calcined catalysts were reduced under $\mathrm{H}_{2}$ stream with the flow rate of 80 $\mathrm{mL} \min ^{-1}$ at $500^{\circ} \mathrm{C}$ for $1 \mathrm{~h}$. 
For bimetallic catalysts, $\mathrm{NiMo} / \mathrm{Al}_{2} \mathrm{O}_{3}$ and $\mathrm{CoMo} / \mathrm{Al}_{2} \mathrm{O}_{3}$, an additional Mo precursor was used, which was $\left(\mathrm{NH}_{4}\right)_{6} \mathrm{Mo}_{7}$. $4 \mathrm{H}_{2} \mathrm{O}\left(1235.86 \mathrm{~g} \mathrm{~mol}^{-1}\right)$. To prepare the $\mathrm{Ni}-\mathrm{Mo} / \mathrm{Al}_{2} \mathrm{O}_{3}$ catalyst at the weight ratio of $\mathrm{Ni} / \mathrm{Mo}$ at $1: 1, \mathrm{Ni}\left(\mathrm{NO}_{3}\right)_{2} \cdot 6 \mathrm{H}_{2} \mathrm{O}$ was mixed with $\left(\mathrm{NH}_{4}\right)_{6} \mathrm{Mo}_{7} \cdot 4 \mathrm{H}_{2} \mathrm{O}$ to maintain $5 \% \mathrm{w} / \mathrm{w}$ based on the $\mathrm{Al}_{2} \mathrm{O}_{3}$ support and subsequently dissolved in $5 \mathrm{~mL}$ of deionized water. In the case of $\mathrm{CoMo} / \mathrm{Al}_{2} \mathrm{O}_{3}$ synthesis, a $\mathrm{Co}\left(\mathrm{NO}_{3}\right)_{2} \cdot 6 \mathrm{H}_{2} \mathrm{O}$ precursor was mixed with $\left(\mathrm{NH}_{4}\right)_{6} \mathrm{Mo}_{7} \cdot 4 \mathrm{H}_{2} \mathrm{O}$ at $5 \% \mathrm{w} / \mathrm{w}$ based on the $\mathrm{Al}_{2} \mathrm{O}_{3}$ support and then dissolved in 5 $\mathrm{mL}$ of deionized water. The solution was added dropwise over the dry $\mathrm{Al}_{2} \mathrm{O}_{3}$ support and followed by calcination and $\mathrm{H}_{2}$ reduction before use according to the procedure aforementioned.

4.4. Catalytic HDO of Light Bio-oil from Solvothermal Liquefaction of EFB. The upgrading of bio-oil derived from solvothermolysis liquefaction of EFB was performed in a $100 \mathrm{~mL}$ rotating-bed reactor. Into the reactor, $20 \mathrm{~g}$ of light bio-oil and $2 \mathrm{~g}$ of the synthesized catalyst (10 wt \% catalyst loading) were added. The reaction system was flushed with $\mathrm{H}_{2}$ gas several times to ensure that the oxygen was removed. The catalytic $\mathrm{HDO}$ of bio-oil was then initiated under $2 \mathrm{MPa}$ of initial $\mathrm{H}_{2}$ pressure at 300 and $350{ }^{\circ} \mathrm{C}$ with a heating rate of $12{ }^{\circ} \mathrm{C} \mathrm{min}-1$. The rotation speed of the catalyst bed was kept constant at 250 $\mathrm{rpm}$, and the reaction time was $1 \mathrm{~h}$. After the reaction, the upgraded bio-oil was cooled down using a refrigeration system.

4.5. Characterization of Synthesized Catalysts. The physical and morphological characterization of synthesized catalysts was performed by scanning electron microscope (SEM) and transmission electron microscopy (TEM, JEM$2100 / \mathrm{HR}(200 \mathrm{kV})$, resolution point $0.23 \mathrm{~nm}$ and lattice 0.14 $\mathrm{nm}$, single tilt and double tilt $\left( \pm 30^{\circ}\right)$ holder $)$. X-ray diffraction (XRD) was applied for the identification of metal crystallization using an XRD spectrometer equipped with a $\mathrm{Cu}$ tube (XRD, Malvern PANalytical, Model Aeris, Netherland) with a $0.02^{\circ}$ $\min ^{-1}$ scan rate from $2 \theta=10$ to $80^{\circ}$. The suitable temperature for catalyst reduction was analyzed by $\mathrm{H}_{2}$-temperature programmed reduction $\left(\mathrm{H}_{2}\right.$-TPR) using $200 \mathrm{mg}$ of the catalyst at $20 \mathrm{~mL} \mathrm{~min}^{-1}$ flow rate of Ar at $400^{\circ} \mathrm{C}$ for $40 \mathrm{~min}$. Then, the temperature was decreased to $40{ }^{\circ} \mathrm{C}$, and subsequently, the catalyst was reduced in a $5 \% \mathrm{H}_{2} / \mathrm{Ar}$ stream with a heating rate of $10{ }^{\circ} \mathrm{C} \mathrm{min}{ }^{-1}$ up to $800{ }^{\circ} \mathrm{C}$. The valence electron of elemental atomic surface and the chemical binding and composition on the surface of the synthesized catalyst were analyzed by X-ray photoelectron spectroscopy (XPS) (AXIS Ultra DLD model, Kratos Analytical Ltd., U.K.). Nitrogen adsorption and desorption isotherms $\left(280{ }^{\circ} \mathrm{C}\right)$ as well as the BET surface area, pore size diameter, and pore volume distribution of the support and reduced catalysts were analyzed (BELSORP-mini II model, BEL, Japan) using $150{ }^{\circ} \mathrm{C}, 6 \mathrm{~h}$ degas conditions.

4.6. Characterization of Upgraded Bio-oil from the HDO Process. Functional groups in bio-oil products were analyzed by Fourier transform infrared (FT-IR) spectroscopy using Nicolet 6700 model, Thermo Fisher Scientific. The measurement was performed in the wavenumber ranging from 4000 to $400 \mathrm{~cm}^{-1}$ for 100 scan numbers with $4 \mathrm{~cm}^{-1}$ resolutions. Compositional analysis of bio-oil as the mass percentage of $\mathrm{C}, \mathrm{H}$, $\mathrm{O}$, and $\mathrm{N}$ was performed by a CHNS/O analyzer (2400 series II, PerkinElmer). A bomb calorimeter (PARR 1261, USA) was operated for the measurement of the higher heating value (HHV) of bio-oil when $1 \mathrm{~g}$ of benzoic acid was used as a heat of combustion standard compared with the heat of combustion of the tested sample by burning $1.00 \pm 0.05 \mathrm{~g}$ of the sample in the bomb calorimeter. The heat of combustion was computed based on the temperatures before and after combustion.

For identification of chemical constituents in bio-oil, gas chromatography-mass spectrometry (GC-MS) was performed after bio-oil toluene extraction. First, bio-oil was centrifuged to remove the solid particles and then extracted with toluene in a ratio of oil to toluene at 3:7 (v/v). GC-MS analysis (Agilent Technologies $6890 \mathrm{~N}$ ) was performed using an HP-5MS UI column $(30 \mathrm{~m} \times 0.25 \mathrm{~mm} \times 0.25 \mu \mathrm{m})$. Helium was the carrier gas at the flow rate of $1 \mu \mathrm{L} \mathrm{min}{ }^{-1}$. An injector temperature of 300 ${ }^{\circ} \mathrm{C}$, an interface temperature of $280{ }^{\circ} \mathrm{C}$, and a detector temperature of $250{ }^{\circ} \mathrm{C}$ were applied. The amount of the injected sample was $2 \mu \mathrm{m}$, and the split ratio was $10 / 1$. The operating temperature for GC-MS analysis was controlled at 50 ${ }^{\circ} \mathrm{C}$ (maintained for $2 \mathrm{~min}$ ) and then increased to $290{ }^{\circ} \mathrm{C}$ (maintained for $5 \mathrm{~min}$ ) with the heating rate of $8{ }^{\circ} \mathrm{C} \mathrm{min}^{-1}$.

Bio-oil yields were calculated by dividing the bio-oil weight ( $w_{\text {bio-oil }}$ in $\mathrm{g}$ ) by the total weight of initial dry EFB and glycerol after microwave torrefaction ( $w_{\text {total }}$ in $\left.\mathrm{g}\right)$, as shown in eq $1:^{88}$

$$
\text { bio-oil yield }(\%)=\frac{w_{\text {bio-oil }}}{w_{\text {total }}} \times 100
$$

In the case of catalytic HDO bio-oil, the weight of upgraded biooil was recorded for the calculation of HHVs and energy ratio. The energy ratio $(r)$ of the product was calculated based on the ratio of $\mathrm{HHV}$ of upgraded $\mathrm{HDO}$ bio-oil $\left(\mathrm{HHV}_{\mathrm{HDO}}, \mathrm{MJ} \mathrm{kg}^{-1}\right)$ and that of raw bio-oil $\left(\mathrm{HHV}_{0}, \mathrm{MJ} \mathrm{kg}^{-1}\right)$. The energy yield $\left(Y_{\mathrm{E}}\right)$ could be calculated when $Y_{\text {HDO }}$ is the mass yield of upgraded HDO bio-oil (wt \%).

$$
\begin{aligned}
& r=\frac{\mathrm{HHV}_{\mathrm{HDO}}}{\mathrm{HHV}_{0}} \\
& Y_{\mathrm{E}}=\frac{\mathrm{HHV}_{\mathrm{HDO}} \cdot Y_{\mathrm{HDO}}}{\mathrm{HHV}}=r \cdot Y_{\mathrm{HDO}}
\end{aligned}
$$

The carbon yield of upgraded bio-oil products was calculated from the number of moles of carbon from CHNS/O elemental analysis in the product $\left(n_{\mathrm{C} \text {,product }}\right)$ divided by the number of moles of carbon in raw $\operatorname{EFB}\left(n_{\mathrm{C} \text {,raw material }}\right)$.

$$
\text { carbon yield }(\%)=\frac{n_{\mathrm{C} \text {,product }}}{n_{\mathrm{C}, \text { raw material }}} \times 100
$$

\section{ASSOCIATED CONTENT}

\section{Supporting Information}

The Supporting Information is available free of charge at https://pubs.acs.org/doi/10.1021/acsomega.0c05387.

Biomass solvothermolysis liquefaction system for production of heavy bio-oil and light bio-oil from a palm empty fruit bunch (EFB) as well as extracted light bio-oil (LBO), heavy bio-oil (HBO), and crude carbon; textural properties of reduced catalysts, i.e., BET surface area, pore size diameter, and pore volume as well as nitrogen adsorption/desorption isotherms of all calcined catalysts; gas chromatography-mass spectroscopic analysis of products from upgrading bio-oil using hydrodeoxygenation catalyzed by $\mathrm{CoMo} / \mathrm{Al}_{2} \mathrm{O}_{3}$ and $\mathrm{NiMo} / \mathrm{Al}_{2} \mathrm{O}_{3}$ at different temperatures $\left(300\right.$ and $350{ }^{\circ} \mathrm{C}$ ) at initial $2 \mathrm{MPa}$ $\mathrm{H}_{2}$ pressure for $1 \mathrm{~h}$ reaction time; comparison of main products of hydrodeoxygenated bio-oil from this study and previous studies (PDF) 


\section{AUTHOR INFORMATION}

\section{Corresponding Author}

Chularat Sakdaronnarong - Department of Chemical Engineering, Faculty of Engineering, Mahidol University, Phutthamonthon, Nakhon Pathom 73170, Thailand; (1) orcid.org/0000-0002-0195-2236; Phone: +6628892138; Email: chularat.sak@mahidol.ac.th; Fax: +6624419731

\section{Authors}

Chutanan Muangsuwan - Department of Chemical Engineering, Faculty of Engineering, Mahidol University, Phutthamonthon, Nakhon Pathom 73170, Thailand

Warangthat Kriprasertkul - Department of Chemical Engineering, Faculty of Engineering, Mahidol University, Phutthamonthon, Nakhon Pathom 73170, Thailand

Sakhon Ratchahat - Department of Chemical Engineering, Faculty of Engineering, Mahidol University, Phutthamonthon, Nakhon Pathom 73170, Thailand

Chen-Guang Liu - State Key Laboratory of Microbial Metabolism, Joint International Research Laboratory of Metabolic o Developmental Sciences, School of Life Sciences and Biotechnology, Shanghai Jiao Tong University, Shanghai 200240, China; 이이.orido000-0003-0343-6304

Pattaraporn Posoknistakul - Department of Chemical Engineering, Faculty of Engineering, Mahidol University, Phutthamonthon, Nakhon Pathom 73170, Thailand; () orcid.org/0000-0002-7270-1012

Navadol Laosiripojana - The Joint Graduate School of Energy and Environment, King Mongkut's University of Technology Thonburi, Bangkok 10140, Thailand

Complete contact information is available at:

https://pubs.acs.org/10.1021/acsomega.0c05387

\section{Notes}

The authors declare no competing financial interest.

\section{ACKNOWLEDGMENTS}

This work was supported by a Mid-Career Research Grant from the Thailand Research Fund (RSA6280074). N.L. was supported by the Thailand Research Fund (RTA628008). C.M. and W.K. are grateful for the partial support from the Energy Policy and Planning Office (EPPO), Ministry of Energy, Thailand.

\section{REFERENCES}

(1) Liao, Y.-T.; Matsagar, B. M.; Wu, K. C. W. Metal-Organic Framework (MOF)-Derived Effective Solid Catalysts for Valorization of Lignocellulosic Biomass. ACS Sustainable Chem. Eng. 2018, 6, 13628-13643.

(2) Liao, Y.-T.; Nguyen, V. C.; Ishiguro, N.; Young, A. P.; Tsung, C.K.; Wu, K. C. W. Engineering a homogeneous alloy-oxide interface derived from metal-organic frameworks for selective oxidation of 5hydroxymethylfurfural to 2,5-furandicarboxylic acid. Appl. Catal., B 2020, 270, No. 118805 .

(3) Dutta, S.; Kim, J.; Ide, Y.; Ho Kim, J.; Hossain, M. S. A.; Bando, Y.; Yamauchi, Y.; Wu, K. C. W. 3D network of cellulose-based energy storage devices and related emerging applications. Mater. Horiz. 2017, $4,522-545$.

(4) Yang, J.; He, Q.; Yang, L. A review on hydrothermal coliquefaction of biomass. Appl. Energy 2019, 250, 926-945.

(5) Isa, K. M.; Abdullah, T. A. T.; Ali, U. F. M. Hydrogen donor solvents in liquefaction of biomass: A review. Renewable Sustainable Energy Rev. 2018, 81, 1259-1268.
(6) Koriakin, A.; Moon, S.; Kim, D.-W.; Lee, C.-H. Liquefaction of oil palm empty fruit bunch using sub- and supercritical tetralin, ndodecane, and their mixture. Fuel 2017, 208, 184-192.

(7) Huang, H.-j.; Yuan, X.-z.; Zeng, G.-m.; Liu, Y.; Li, H.; Yin, J.; Wang, X.-1. Thermochemical liquefaction of rice husk for bio-oil production with sub- and supercritical ethanol as solvent. J. Anal. Appl. Pyrolysis 2013, 102, 60-67.

(8) Matsagar, B. M.; Wang, Z.-Y.; Sakdaronnarong, C.; Chen, S. S.; Tsang, D. C. W.; Wu, K. C.-W. Effect of Solvent, Role of Formic Acid and $\mathrm{Rh} / \mathrm{C}$ Catalyst for the Efficient Liquefaction of Lignin. ChemCatChem 2019, 11, 4604-4616.

(9) Mena-Cervantes, V. Y.; Hernández-Altamirano, R.; TiscareñoFerrer, A. Development of a green one-step neutralization process for valorization of crude glycerol obtained from biodiesel. Environ. Sci. Pollut. Res. 2020, 27, 28500-28509.

(10) Sangjan, A.; Ngamsiri, P.; Klomkliang, N.; Wu, K. C. W.; Matsagar, B. M.; Ratchahat, S.; Liu, C.-G.; Laosiripojana, N.; Sakdaronnarong, C. Effect of microwave-assisted wet torrefaction on liquefaction of biomass from palm oil and sugarcane wastes to bio-oil and carbon nanodots/nanoflakes by hydrothermolysis and solvothermolysis. Renewable Energy 2020, 154, 1204-1217.

(11) Kim, S.; Kwon, E. E.; Kim, Y. T.; Jung, S.; Kim, H. J.; Huber, G. W.; Lee, J. Recent advances in hydrodeoxygenation of biomass-derived oxygenates over heterogeneous catalysts. Green Chem. 2019, 21, 37153743.

(12) Oh, S.; Choi, H. S.; Kim, U.-J.; Choi, I.-G.; Choi, J. W. Storage performance of bio-oil after hydrodeoxygenative upgrading with noble metal catalysts. Fuel 2016, 182, 154-160.

(13) Zhu, X.; Lobban, L. L.; Mallinson, R. G.; Resasco, D. E. Bifunctional transalkylation and hydrodeoxygenation of anisole over a Pt/HBeta catalyst. J. Catal. 2011, 281, 21-29.

(14) Payormhorm, J.; Kangvansaichol, K.; Reubroycharoen, P.; Kuchonthara, P.; Hinchiranan, N. Pt/Al2O3-catalytic deoxygenation for upgrading of Leucaena leucocephala-pyrolysis oil. Bioresour. Technol. 2013, 139, 128-135.

(15) Mukundan, S.; Konarova, M.; Atanda, L.; Ma, Q.; Beltramini, J. Guaiacol hydrodeoxygenation reaction catalyzed by highly dispersed, single layered MoS2/C. Catal. Sci. Technol. 2015, 5, 4422-4432.

(16) Jin, S.; Xiao, Z.; Li, C.; Chen, X.; Wang, L.; Xing, J.; Li, W.; Liang, C. Catalytic hydrodeoxygenation of anisole as lignin model compound over supported nickel catalysts. Catal. Today 2014, 234, 125-132.

(17) Mora-Vergara, I. D.; Hernández Moscoso, L.; Gaigneaux, E. M.; Giraldo, S. A.; Baldovino-Medrano, V. G. Hydrodeoxygenation of guaiacol using NiMo and CoMo catalysts supported on alumina modified with potassium. Catal. Today 2018, 302, 125-135.

(18) Laurent, E.; Delmon, B. Study of the hydrodeoxygenation of carbonyl, carboxylic and guaiacyl groups over sulfided $\mathrm{CoMo} / \gamma-\mathrm{Al} 2 \mathrm{O} 3$ and $\mathrm{NiMo} / \gamma-\mathrm{Al} 2 \mathrm{O} 3$ catalyst: II. Influence of water, ammonia and hydrogen sulfide. Appl. Catal., A 1994, 109, 97-115.

(19) Krár, M.; Kovács, S.; Kalló, D.; Hancsók, J. Fuel purpose hydrotreating of sunflower oil on $\mathrm{CoMo} / \mathrm{Al} 2 \mathrm{O} 3$ catalyst. Bioresour. Technol. 2010, 101, 9287-9293.

(20) Anand, M.; Sinha, A. K. Temperature-dependent reaction pathways for the anomalous hydrocracking of triglycerides in the presence of sulfided Co-Mo-catalyst. Bioresour. Technol. 2012, 126, $148-155$.

(21) Coumans, A. E.; Hensen, E. J. M. A real support effect on the hydrodeoxygenation of methyl oleate by sulfided NiMo catalysts. Catal. Today 2017, 298, 181-189.

(22) Deliy, I. V.; Vlasova, E. N.; Nuzhdin, A. L.; Gerasimov, E. Y.; Bukhtiyarova, G. A. Hydrodeoxygenation of methyl palmitate over sulfided $\mathrm{Mo} / \mathrm{Al} 2 \mathrm{O} 3, \mathrm{CoMo} / \mathrm{Al} 2 \mathrm{O} 3$ and $\mathrm{NiMo} / \mathrm{Al} 2 \mathrm{O} 3$ catalysts. RSC Adv. 2014, 4, 2242-2250.

(23) Anand, M.; Farooqui, S. A.; Kumar, R.; Joshi, R.; Kumar, R.; Sibi, M. G.; Singh, H.; Sinha, A. K. Optimizing renewable oil hydrocracking conditions for aviation bio-kerosene production. Fuel Process. Technol. 2016, 151, 50-58.

(24) Tiwari, R.; Rana, B. S.; Kumar, R.; Verma, D.; Kumar, R.; Joshi, R. K.; Garg, M. O.; Sinha, A. K. Hydrotreating and hydrocracking catalysts 
for processing of waste soya-oil and refinery-oil mixtures. Catal. Commun. 2011, 12, 559-562.

(25) Jong, S.-J.; Cheng, S. Reduction behavior and catalytic properties of cobalt containing ZSM-5 zeolites. Appl. Catal., A 1995, 126, 51-66.

(26) Kantarelis, E.; Javed, R.; Stefanidis, S.; Psarras, A.; Iliopoulou, E.; Lappas, A. Engineering the Catalytic Properties of HZSM5 by Cobalt Modification and Post-synthetic Hierarchical Porosity Development. Top. Catal. 2019, 62, 773-785.

(27) Wang, W.-J.; Chen, Y.-W. Influence of metal loading on the reducibility and hydrogenation activity of cobalt/alumina catalysts. Appl. Catal. 1991, 77, 223-233.

(28) Xiong, H.-f.; Zhang, Y.-h.; Li, J.-1.; Gu, Y.-y. Effect of cobalt loading on reducibility, dispersion and crystallite size of $\mathrm{Co} / \mathrm{Al} 2 \mathrm{O} 3$ fischer-tropsch catalyst. J. Cent. South Univ. Technol. 2004, 11, 414418.

(29) Mihet, M.; Lazar, M. D. Effect of Pd and Rh promotion on Ni/ $\mathrm{Al} 2 \mathrm{O} 3$ for $\mathrm{NO}$ reduction by hydrogen for stationary applications. Chem. Eng. J. 2014, 251, 310-318.

(30) Maia, A. J.; Louis, B.; Lam, Y. L.; Pereira, M. M. Ni-ZSM-5 catalysts: Detailed characterization of metal sites for proper catalyst design. J. Catal. 2010, 269, 103-109.

(31) Chen, J.; Mi, J.; Li, K.; Wang, X.; Dominguez Garcia, E.; Cao, Y.; Jiang, L.; Oliviero, L.; Maugé, F. Role of Citric Acid in Preparing Highly Active $\mathrm{CoMo} / \mathrm{Al} 2 \mathrm{O} 3$ Catalyst: From Aqueous Impregnation Solution to Active Site Formation. Ind. Eng. Chem. Res. 2017, 56, 14172-14181.

(32) Bykova, M. V.; Ermakov, D. Y.; Kaichev, V. V.; Bulavchenko, O. A.; Saraev, A. A.; Lebedev, M. Y.; Yakovlev, VA. Ni-based sol-gel catalysts as promising systems for crude bio-oil upgrading: Guaiacol hydrodeoxygenation study. Appl. Catal., B 2012, 113-114, 296-307.

(33) Borowiecki, T.; Gac, W.; Denis, A. Effects of small $\mathrm{MoO} 3$ additions on the properties of nickel catalysts for the steam reforming of hydrocarbons: III. Reduction of Ni-Mo/Al2O3 catalysts. Appl. Catal., A 2004, 270, 27-36.

(34) Calafat, A.; Laine, J.; López-Agudo, A.; Palacios, J. M. Effect of Surface Oxidation of the Support on the Thiophene Hydrodesulfurization Activity of $\mathrm{Mo}, \mathrm{Ni}$, and NiMo Catalysts Supported on Activated Carbon. J. Catal. 1996, 162, 20-30.

(35) Liu, Q.; Wang, A.; Wang, X.; Gao, P.; Wang, X.; Zhang, T. Synthesis, characterization and catalytic applications of mesoporous $\gamma$ alumina from boehmite sol. Microporous Mesoporous Mater. 2008, 111, 323-333.

(36) Xing, W.; Li, F.; Yan, Z.-f.; Lu, G. Q. Synthesis and electrochemical properties of mesoporous nickel oxide. J. Power Sources 2004, 134, 324-330.

(37) Chang, S. K.; Zainal, Z.; Tan, K. B.; Yusof, N. A.; Yusoff, W. M. D. W.; Prabaharan, S. R. S. Surface morphology and crystallinity of metal oxides in nickel-cobalt binary system. Sains Malays. 2012, 41, 465-470.

(38) Muhammad, Y.; Shoukat, A.; Rahman, A. U.; Rashid, H. U.; Ahmad, W. Oxidative desulfurization of dibenzothiophene over $\mathrm{Fe}$ promoted $\mathrm{Co}-\mathrm{Mo} / \mathrm{Al} 2 \mathrm{O} 3$ and $\mathrm{Ni}-\mathrm{Mo} / \mathrm{Al} 2 \mathrm{O} 3$ catalysts using hydrogen peroxide and formic acid as oxidants. Chin. J. Chem. Eng. 2018, 26, 593-600.

(39) Liu, F.; Xu, S.; Cao, L.; Chi, Y.; Zhang, T.; Xue, D. A Comparison of NiMo/Al2O3 Catalysts Prepared by Impregnation and Coprecipitation Methods for Hydrodesulfurization of Dibenzothiophene. J. Phys. Chem. C 2007, 111, 7396-7402.

(40) Lv, M.; Xie, W.; Sun, S.; Wu, G.; Zheng, L.; Chu, S.; Gao, C.; Bao, J. Activated-carbon-supported $\mathrm{K}-\mathrm{Co}-\mathrm{Mo}$ catalysts for synthesis of higher alcohols from syngas. Catal. Sci. Technol. 2015, 5, 2925-2934.

(41) Liu, Z.; Zhan, C.; Peng, L.; Cao, Y.; Chen, Y.; Ding, S.; Xiao, C.; Lai, X.; Li, J.; Wei, S.; Wang, J.; Tu, J. A CoMoO4-Co2Mo3O8 heterostructure with valence-rich molybdenum for a high-performance hydrogen evolution reaction in alkaline solution. J. Mater. Chem. A 2019, 7, 16761-16769.

(42) Zhang, Q.; Wu, T.; Zhang, P.; Qi, R.; Huang, R.; Song, X.; Gao, L. Facile synthesis of hollow hierarchical $\mathrm{Ni} / \gamma$ - $\mathrm{Al} 2 \mathrm{O} 3$ nanocomposites for methane dry reforming catalysis. RSC Adv. 2014, 4, 51184-51193.
(43) Jung, J.-S.; Choi, G.; Lee, J.-S.; Ramesh, S.; Moon, D. J. Microstructure of FTS studies over spherical $\mathrm{Co} / \gamma$-Al2O3. Catal. Today 2015, 250, 102-114.

(44) Looi, P. Y.; Mohamed, A. R.; Tye, C. T. Hydrocracking of residual oil using molybdenum supported over mesoporous alumina as a catalyst. Chem. Eng. J. 2012, 181-182, 717-724.

(45) Zhang, J.; Jiang, Z. Q.; Li, J. J.; Du, X. G.; Song, B. C. Controllable Preparation of Multishaped Micro/Nanosized Hydrated Nickel Molybdate via Chelator-Assisted Hydrothermal Route. Adv. Mater. Res. 2013, 750-752, 249-252.

(46) Zhang, C.; Brorson, M.; Li, P.; Liu, X.; Liu, T.; Jiang, Z.; Li, C. $\mathrm{CoMo} / \mathrm{Al} 2 \mathrm{O} 3$ catalysts prepared by tailoring the surface properties of alumina for highly selective hydrodesulfurization of FCC gasoline. Appl. Catal., A 2019, 570, 84-95.

(47) Choi, J. G.; Thompson, L. T. XPS study of as-prepared and reduced molybdenum oxides. Appl. Surf. Sci. 1996, 93, 143-149.

(48) Salahudeen, N.; Ahmed, A. S.; Al-Muhtaseb, A. H.; Dauda, M.; Waziri, S. M.; Jibril, B. Y.; Al-Sabahi, J. Synthesis, characterization and adsorption study of nano-sized activated alumina synthesized from kaolin using novel method. Powder Technol. 2015, 280, 266-272.

(49) Muhammad, Y.; Rashid, H. U.; Subhan, S.; Rahman, A. U.; Sahibzada, M.; Tong, Z. Boosting the hydrodesulfurization of dibenzothiophene efficiency of $\mathrm{Mn}$ decorated $(\mathrm{Co} / \mathrm{Ni})-\mathrm{Mo} / \mathrm{Al} 2 \mathrm{O} 3$ catalysts at mild temperature and pressure by coupling with phosphonium based ionic liquids. Chem. Eng. J. 2019, 375, No. 121957.

(50) Zhang, J.; Fidalgo, B.; Kolios, A.; Shen, D.; Gu, S. Mechanism of deoxygenation in anisole decomposition over single-metal loaded HZSM-5: Experimental study. Chem. Eng. J. 2018, 336, 211-222.

(51) Salahudeen, N.; Ahmed, A. S.; Al-Muhtaseb, A. aH.; Dauda, M.; Waziri, S. M.; Jibril, B. Y. Synthesis of gamma alumina from Kankara kaolin using a novel technique. Appl. Clay Sci. 2015, 105-106, 170177.

(52) Guo, B.; Walter, V.; Hornung, U.; Dahmen, N. Hydrothermal liquefaction of Chlorella vulgaris and Nannochloropsis gaditana in a continuous stirred tank reactor and hydrotreating of biocrude by nickel catalysts. Fuel Process. Technol. 2019, 191, 168-180.

(53) Santillan-Jimenez, E.; Pace, R.; Morgan, T.; Behnke, C.; Sajkowski, D. J.; Lappas, A.; Crocker, M. Co-processing of hydrothermal liquefaction algal bio-oil and petroleum feedstock to fuel-like hydrocarbons via fluid catalytic cracking. Fuel Process. Technol. 2019, 188, 164-171.

(54) Kök, M. V.; Varfolomeev, M. A.; Nurgaliev, D. K. Crude oil characterization using TGA-DTA, TGA-FTIR and TGA-MS techniques. J. Pet. Sci. Eng. 2017, 154, 537-542.

(55) Richard, C. J.; Patel, B.; Chadwick, D.; Hellgardt, K. Hydrothermal deoxygenation of pyrolysis oil from Norwegian spruce: Picea abies. Biomass Bioenergy 2013, 56, 446-455.

(56) Aboulkas, A.; Hammani, H.; El Achaby, M.; Bilal, E.; Barakat, A.; El harfi, K. Valorization of algal waste via pyrolysis in a fixed-bed reactor: Production and characterization of bio-oil and bio-char. Bioresour. Technol. 2017, 243, 400-408.

(57) Li, J.; Yan, R.; Xiao, B.; Wang, X.; Yang, H. Influence of Temperature on the Formation of Oil from Pyrolyzing Palm Oil Wastes in a Fixed Bed Reactor. Energy Fuels 2007, 21, 2398-2407.

(58) Abnisa, F.; Arami-Niya, A.; Daud, W. M. A. W.; Sahu, J. N. Characterization of Bio-oil and Bio-char from Pyrolysis of Palm Oil Wastes. BioEnergy Res. 2013, 6, 830-840.

(59) Templis, C. C.; Revelas, C. J.; Papastylianou, A. A.; Papayannakos, N. G. Phenol Hydrodeoxygenation over a Reduced and Sulfided NiMo/ $\gamma$-Al2O3 Catalyst. Ind. Eng. Chem. Res. 2019, 58, $6278-6287$

(60) Jin, W.; Pastor-Pérez, L.; Shen, D.; Sepúlveda-Escribano, A.; Gu, S.; Ramirez Reina, T. Catalytic Upgrading of Biomass Model Compounds: Novel Approaches and Lessons Learnt from Traditional Hydrodeoxygenation - a Review. ChemCatChem 2019, 11, 924-960.

(61) Prasomsri, T.; Shetty, M.; Murugappan, K.; Román-Leshkov, Y. Insights into the catalytic activity and surface modification of $\mathrm{MoO} 3$ during the hydrodeoxygenation of lignin-derived model compounds 
into aromatic hydrocarbons under low hydrogen pressures. Energy Environ. Sci. 2014, 7, 2660-2669.

(62) Mäki-Arvela, P.; Murzin, D. Y. Hydrodeoxygenation of LigninDerived Phenols: From Fundamental Studies towards Industrial Applications. Catalysts 2017, 7, No. 265.

(63) Lyu, G.; Wu, S.; Zhang, H. Estimation and Comparison of BioOil Components from Different Pyrolysis Conditions. Front. Energy Res. 2015, 3, No. 28.

(64) Sheng, X.; Li, G.; Wang, W.; Cong, Y.; Wang, X.; Huber, G. W.; Li, N.; Wang, A.; Zhang, T. Dual-bed catalyst system for the direct synthesis of high density aviation fuel with cyclopentanone from lignocellulose. AIChE J. 2016, 62, 2754-2761.

(65) Hronec, M.; Fulajtarová, K. Selective transformation of furfural to cyclopentanone. Catal. Commun. 2012, 24, 100-104.

(66) Yang, Y.; Du, Z.; Huang, Y.; Lu, F.; Wang, F.; Gao, J.; Xu, J. Conversion of furfural into cyclopentanone over $\mathrm{Ni}-\mathrm{Cu}$ bimetallic catalysts. Green Chem. 2013, 15, 1932-1940.

(67) Guo, J.; Xu, G.; Han, Z.; Zhang, Y.; Fu, Y.; Guo, Q. Selective Conversion of Furfural to Cyclopentanone with CuZnAl Catalysts. ACS Sustainable Chem. Eng. 2014, 2, 2259-2266.

(68) Zhu, H.; Zhou, M.; Zeng, Z.; Xiao, G.; Xiao, R. Selective hydrogenation of furfural to cyclopentanone over $\mathrm{Cu}-\mathrm{Ni}$-Al hydrotalcite-based catalysts. Korean J. Chem. Eng. 2014, 31, 593-597.

(69) Wang, W.; Li, N.; Li, G.; Li, S.; Wang, W.; Wang, A.; Cong, Y.; Wang, X.; Zhang, T. Synthesis of Renewable High-Density Fuel with Cyclopentanone Derived from Hemicellulose. ACS Sustainable Chem. Eng. 2017, 5, 1812-1817.

(70) Dohade, M.; Dhepe, P. L. Efficient method for cyclopentanone synthesis from furfural: understanding the role of solvents and solubility in a bimetallic catalytic system. Catal. Sci. Technol. 2018, 8, 5259-5269.

(71) Shen, T.; Hu, R.; Zhu, C.; Li, M.; Zhuang, W.; Tang, C.; Ying, H. Production of cyclopentanone from furfural over $\mathrm{Ru} / \mathrm{C}$ with Al11.6PO23.7 and application in the synthesis of diesel range alkanes. RSC Adv. 2018, 8, 37993-38001.

(72) Yang, T.; Shi, L.; Li, R.; Li, B.; Kai, X. Hydrodeoxygenation of crude bio-oil in situ in the bio-oil aqueous phase with addition of zerovalent aluminum. Fuel Process. Technol. 2019, 184, 65-72.

(73) Remón, J.; Ochoa, E.; Foguet, C.; Pinilla, J. L.; Suelves, I. Towards a sustainable bio-fuels production from lignocellulosic biooils: Influence of operating conditions on the hydrodeoxygenation of guaiacol over a Mo2C/CNF catalyst. Fuel Process. Technol. 2019, 191, $111-120$.

(74) Sepúlveda, C.; Leiva, K.; García, R.; Radovic, L. R.; Ghampson, I. T.; DeSisto, W. J.; Fierro, J. L. G.; Escalona, N. Hydrodeoxygenation of 2-methoxyphenol over Mo2N catalysts supported on activated carbons. Catal. Today 2011, 172, 232-239.

(75) Boscagli, C.; Raffelt, K.; Grunwaldt, J.-D. Reactivity of platform molecules in pyrolysis oil and in water during hydrotreatment over nickel and ruthenium catalysts. Biomass Bioenergy 2017, 106, 63-73.

(76) Hernández-Huesca, R.; Mérida-Robles, J.; Maireles-Torres, P.; Rodríguez-Castellón, E.; Jiménez-López, A. Hydrogenation and RingOpening of Tetralin on Ni and NiMo Supported on Alumina-Pillared $\alpha$-Zirconium Phosphate Catalysts. A Thiotolerance Study. J. Catal. 2001, 203, 122-132.

(77) Bello, S. S.; Wang, C.; Zhang, M.; Han, Z.; Shi, L.; Wang, K.; Zhong, Z.; Su, F.; Xu, G. Recycling the CoMo/Al2O3 catalyst for effectively hydro-upgrading shale oil with high sulfur content and viscosity. RSC Adv. 2020, 10, 37287-37298.

(78) Wang, W.; Zhang, L.; Han, Y.; Zhang, Y.; Liu, X.; Xu, S. Cleaner recycling of spent $\mathrm{Ni}-\mathrm{Mo} / \gamma$-Al2 3 catalyst based on mineral phase reconstruction. J. Cleaner Prod. 2019, 232, 266-273.

(79) Lanzafame, P.; Temi, D. M.; Perathoner, S.; Spadaro, A. N.; Centi, G. Direct conversion of cellulose to glucose and valuable intermediates in mild reaction conditions over solid acid catalysts. Catal. Today 2012, 179, 178-184.

(80) Yang, T.; Jie, Y.; Li, B.; Kai, X.; Yan, Z.; Li, R. Catalytic hydrodeoxygenation of crude bio-oil over an unsupported bimetallic dispersed catalyst in supercritical ethanol. Fuel Process. Technol. 2016, $148,19-27$.
(81) Dai, L.; He, C.; Wang, Y.; Liu, Y.; Ruan, R.; Yu, Z.; Zhou, Y.; Duan, D.; Fan, L.; Zhao, Y. Hydrothermal pretreatment of bamboo sawdust using microwave irradiation. Bioresour. Technol. 2018, 247, 234-241.

(82) Dai, L.; He, C.; Wang, Y.; Liu, Y.; Yu, Z.; Zhou, Y.; Fan, L.; Duan, D.; Ruan, R. Comparative study on microwave and conventional hydrothermal pretreatment of bamboo sawdust: Hydrochar properties and its pyrolysis behaviors. Energy Convers. Manage. 2017, 146, 1-7.

(83) Chen, J.; Shi, H.; Li, L.; Li, K. Deoxygenation of methyl laurate as a model compound to hydrocarbons on transition metal phosphide catalysts. Appl. Catal., B 2014, 144, 870-884.

(84) Yang, Y.; Ochoa-Hernández, C.; de la Peña O'Shea, V. A.; Pizarro, P.; Coronado, J. M.; Serrano, D. P. Effect of metal-support interaction on the selective hydrodeoxygenation of anisole to aromatics over Ni-based catalysts. Appl. Catal., B 2014, 145, 91-100.

(85) Kelly-Yong, T. L.; Lee, K. T.; Mohamed, A. R.; Bhatia, S. Potential of hydrogen from oil palm biomass as a source of renewable energy worldwide. Energy Policy 2007, 35, 5692-5701.

(86) Loow, Y.-L.; Wu, T. Y.; Yang, G. H.; Md. Jahim, J.; Teoh, W. H.; Mohammad, A. W. Role of energy irradiation in aiding pretreatment of lignocellulosic biomass for improving reducing sugar recovery. Cellulose 2016, 23, 2761-2789.

(87) da Silva, R. B.; Pinto, R. A.; Soares, J. M.; Franco, A.; Correa, M. A.; Bohn, F.; da Costa, J. A. P. Effect of the synthesis method and calcination temperature on the formation of $\mathrm{Ni}-\mathrm{NiO}$ nanocomposites. J. Sol-Gel Sci. Technol. 2019, 91, 286-294.

(88) Mukherjee, I.; Sovacool, B. K. Renewable and, Palm oil-based biofuels and sustainability in southeast Asia: A review of Indonesia, Malaysia, and Thailand. Renewable Sustainable Energy Rev. 2014, 37, 112. 